\title{
A review of chromium(VI) use in chlorate electrolysis: Functions, challenges and suggested alternatives
}

\author{
Balázs Endrődi ${ }^{\mathrm{a}, \mathrm{b}}$, Nina Simic ${ }^{\mathrm{c}}$, Mats Wildlock ${ }^{\mathrm{c}}$, Ann Cornell ${ }^{\mathrm{a}, *}$ \\ a Applied Electrochemistry, School of Chemical Science and Engineering, KTH Royal Institute of Technology, SE 100-44 Stockholm, Sweden \\ ${ }^{\mathrm{b}}$ Department of Physical Chemistry and Materials Science, University of Szeged, H-6720 Szeged, Hungary \\ ${ }^{\mathrm{c}}$ AkzoNobel Pulp and Performance Chemicals, SE 445-80 Bohus, Sweden
}

\section{A R T I C L E I N F O}

\section{Article history:}

Received 16 December 2016

Received in revised form 24 February 2017

Accepted 26 February 2017

Available online 28 February 2017

\section{Keywords:}

chlorate electrolysis

cathode selectivity

hydrogen evolution reaction

chromate

oxygen tolerant cathode

\section{A B S T R A C T}

Sodium chlorate is industrially produced by electrolysis of an aqueous salt solution, in which chromium (VI) constitutes an important excipient component. It is added to a concentration of a few grams $\mathrm{Na}_{2} \mathrm{Cr}_{2} \mathrm{O}_{7}$ /liter to the electrolyte and has several functions in the process, the most important being to increase the Faradaic efficiency for hydrogen evolution in the undivided electrochemical cells. A thin film of $\mathrm{Cr}(\mathrm{OH})_{3} \times \mathrm{nH}_{2} \mathrm{O}$ formed by reductive deposition on the cathodes decreases the rate of unwanted side reactions, while still enabling hydrogen evolution to occur. In addition chromium(VI) buffers the electrolyte at the optimum $\mathrm{pH}$ for operation and promotes the desired homogeneous reactions in the electrolyte bulk. Chromium species also affect the rates of hydrogen and oxygen evolution at the electrodes and are said to protect the steel cathodes from corrosion.

Although chromium(VI) stays in a closed loop during chlorate production, chromate is a highly toxic compound and new REACH legislation therefore intends to phase out its use in Europe from 2017. A production without chromium(VI), with no other process modifications is not possible, and today there are no commercially available alternatives to its addition. Thus, there is an urgent need for European chlorate producers to find solutions to this problem. It is expected that chromium-free production will be a requirement also in other parts of the world, following the European example.

As the chromium(VI) addition affects the chlorate process in many ways its replacement might require a combination of solutions targeting each function separately. The aim of this paper is to explain the role and importance of chromium(VI) in the chlorate manufacturing process. Previous achievements in its replacement are summarized and critically evaluated to expose the current state of the field, and to highlight the most promising avenues to be followed. An attempt is also made to reveal connections with other research fields (e.g. photochemical water splitting, corrosion science) facing similar problems. Allied effort of these different communities is expected to open up research avenues to the mutual benefit of these fields.

(c) 2017 Elsevier Ltd. All rights reserved.

\section{Introduction}

Sodium chlorate is a bulk chemical produced by electrolysis of sodium chloride solutions [1,2]. Its industrial manufacture dates back to the 19th century and has over the years evolved to be one of the major electrochemical industries behind chlor-alkali and alumina production [3]. The total annual production of merchant chlorate was 3.6 million tons in 2015, whereof 3.2 was directed for production of chlorine dioxide used in environmentally friendly Elemental Chlorine Free (ECF) bleaching of pulp [4]. The ECF

\footnotetext{
* Corresponding author.

E-mail address: amco@kth.se (A. Cornell).
}

bleaching is currently regarded as the Best Available Technique [5] and is therefore the preferred choice for new bleached chemical pulp producing plants. This directly influences the need for sodium chlorate on the market. The worldwide sodium chlorate demand has increased with over $30 \%$ over the last $10-15$ years (Fig. 1 ) as the consumption of bleached paper and board has increased. The growth is expected to continue as the use of tissue (kitchen rolls, bathroom tissue etc.) and packaging board increases.

In the early days large amounts of calcium(II) salts were added to the electrolyte to achieve acceptable current efficiency [6,7]. In the end of the 19th and beginning of the 20th century several research groups worked with the chlorate process and at that time it was discovered that the addition of multivalent metal ions could enhance the current efficiency [8]. Especially chromium was 


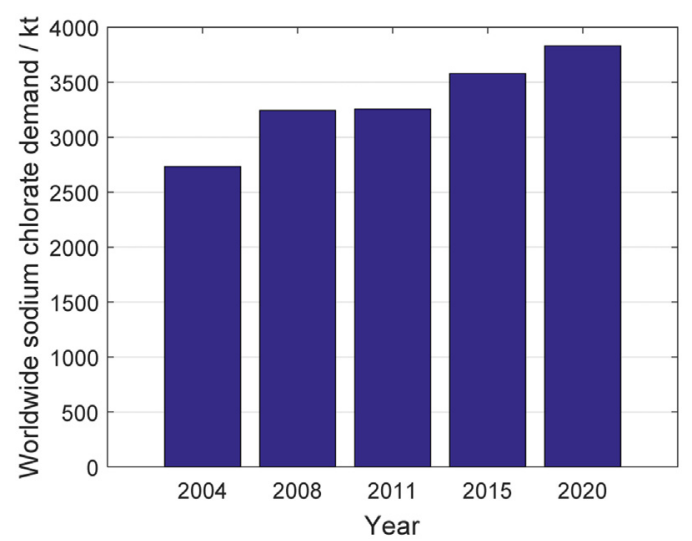

Fig. 1. The annual global sodium chlorate demand in the 21 st century. Data source: IHS Chemical Economics Handbook, 2015 [4].

mentioned and the use of chromate was patented in 1897 by J. Landin [9]. Almost at the same time Imhoff was granted a similar patent in Germany, 1898, and in the United States, 1899 [10]. It should also be noted that Bischoff and Foerster proposed a theory for the function of calcium salts in 1898 describing the formation of a diaphragm, which also became the main explanation for the role of chromate [11]. The invention was described in 1899 by E. Müller as "the electrolysis with chromate present represents one of the most ideal diaphragm processes one can imagine" [12]. Compared to the previous calcium salt based electrolyte current efficiencies were improved from $40 \%$ to almost $90 \%$ [7].

In chlorate manufacture the chromium(VI) substance is most often referred to as sodium dichromate $\left(\mathrm{Na}_{2} \mathrm{Cr}_{2} \mathrm{O}_{7}\right)$ but in the electrolyte the type of chromium substance vary due to chemical and electrochemical reactions and solution $\mathrm{pH}$ and can be found as for example $\mathrm{H}_{2} \mathrm{CrO}_{4}, \mathrm{HCrO}_{4}{ }^{-}, \mathrm{Cr}_{2} \mathrm{O}_{7}{ }^{2-}, \mathrm{CrO}_{4}{ }^{2-}$ and $\mathrm{CrO}_{3} \mathrm{Cl}^{-}$. For the convenience of reading all chromium(VI) compounds will in this paper be referred to as chromium(VI) except when citing references.

The use of chromium(VI) in sodium chlorate production has been accepted as Best Available Technique by the European Commission [1]. Besides all the technical benefits; chromium(VI) substances have for a long time been known to possess hazardous properties and are classified as toxic, corrosive, oxidizing and dangerous to the environment [13]. In addition to this there is also a concern for long-term effects on human health by exposure of chromium(VI) due to its carcinogenic, mutagenic and reprotoxic (CMR) classifications. Therefore chromium(VI) substances have been identified as "substances of very high concern" [14,15]. In 2013 sodium dichromate was included in Annex XIV of REACH meaning that an authorization must be granted by the European commission for continued industrial use after the sunset date 21/ 09/2017 [16]. As one of many industries covered by Annex XIV (e.g. metal finishing), chlorate production was identified and therefore there is an urgent need to find a solution to circumvent the use of chromium(VI) in the process [13]. However, a recent report of an independent third-party organization issued by the chlorate industry states that the unique properties of chromium(VI) serve the chlorate process in several important ways, which makes its replacement very difficult [16]. The socio-economic impact of a complete stop of using sodium dichromate in the production of sodium chlorate and the consequences on the European pulp industry are described in general terms in the public versions of Socio-Economic Analysis provided to the European Chemicals Agency (ECHA) by the producers of sodium chlorate [17-20]. As all these documents conclude there is no currently available technology which could replace the use of chromium(VI). It is therefore predicted in these studies that the European chlorate plants of these companies must be closed down if an authorization is not granted for the continued use of chromium(VI).

The aim of this paper is to explain the multifunctional role that chromium(VI) has in the chlorate manufacturing process and to show the complexity in finding its replacement, to present and discuss alternatives to chromium(VI) suggested in the literature and to point at directions for future research and development towards a chromium(VI)-free chlorate process.

\section{The chlorate process}

Electrochemical production of sodium chlorate is an energy intensive process, as $5-6000 \mathrm{~kW}$ h energy is required to produce a ton of $\mathrm{NaClO}_{3}$ [21]. The core of the process is the electrolysis which takes place in undivided cells. The electrolyte composition and the process conditions are summarized in Table 1.

On the dimensionally stable anodes (DSA) chloride ions are oxidized to chlorine, which then dissolves in the electrolyte and forms chlorate through a complex series of reactions (Reactions (1)-(4)). The most important intermediates are the hypochlorous acid and hypochlorite ion, the sum of which will hereafter be referred to as hypochlorite.

$2 \mathrm{Cl}^{-} \rightarrow \mathrm{Cl}_{2}+2 e^{-}$

$\mathrm{pK}_{\mathrm{h}}=2.98(\mathrm{~T}=\mathrm{RT})[22]$

$$
\mathrm{Cl}_{2}+\mathrm{H}_{2} \mathrm{O} \rightleftharpoons \mathrm{HOCl}+\mathrm{HCl}
$$

$\mathrm{pK}_{\mathrm{a}}=7.0\left(\mathrm{~T}=70^{\circ} \mathrm{C}\right)[23]$

$$
\mathrm{HOCl} \rightleftharpoons \mathrm{ClO}^{-}+\mathrm{H}^{+}
$$

$2 \mathrm{HOCl}+\mathrm{ClO}^{-} \rightarrow \mathrm{ClO}_{3}^{-}+2 \mathrm{Cl}^{-}+2 \mathrm{H}^{+}$

On the cathode, most usually of mild steel, water is reduced to hydrogen gas. Some unwanted reactions, most importantly the reduction of hypochlorite and chlorate ions can also proceed, lowering the energy efficiency of the process. Their negative impact can be minimized to an almost insignificant level by adding chromium(VI) to the solution, which is undoubtedly the most beneficial role of this additive in the process. The chromium(VI) is not consumed in the process.

As it will be discussed throughout the manuscript, the overall efficiency of the chlorate cell is influenced by anodic and cathodic losses during the electrolysis, as well as by unwanted homogeneous reactions. Reliable calculation and reporting of the current (and/or energy) efficiency therefore necessitates either the direct measurement of the actual chlorate production rate, or the measurement of the cell off-gases, and the subsequent calculation of the chlorate formation rate according to the mass-balance equations [24].

Beyond the electrolysis cell, there are several other unit operations involved in the manufacture of sodium chlorate

Table 1

The applied conditions and the solution composition in the electrolytic chlorate production process [21].

\begin{tabular}{ll}
\hline Cell voltage $(\mathrm{V})$ & $2.9-3.7$ \\
Current density $\left(\mathrm{kA} \mathrm{m}^{-2}\right)$ & $1.5-4$ \\
Temperature $\left({ }^{\circ} \mathrm{C}\right)$ & $65-90$ \\
$\mathrm{NaCl}$ concentration $\left(\mathrm{g} \mathrm{dm}^{-3}\right)$ & $70-150$ \\
$\mathrm{NaClO}$ & concentration $\left(\mathrm{g} \mathrm{dm}^{-3}\right)$ \\
$\mathrm{NaOCl}$ concentration $\left(\mathrm{g} \mathrm{dm}^{-3}\right)$ & $450-650$ \\
$\mathrm{Na}_{2} \mathrm{Cr}_{2} \mathrm{O}_{7}$ concentration $\left(\mathrm{g} \mathrm{dm}^{-3}\right)$ & $1-5$ \\
Electrolyte $p \mathrm{H}$ & $1-6$ \\
Electrode distance $(\mathrm{mm})$ & $5.5-7.0$ \\
\hline
\end{tabular}




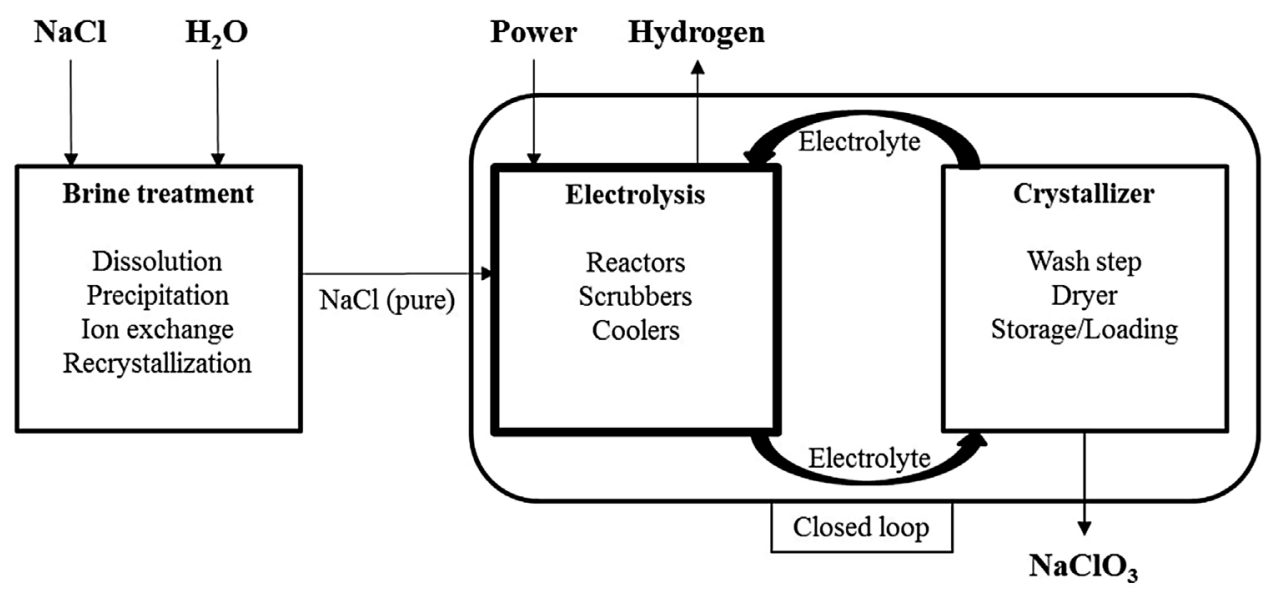

Fig. 2. Schematic model of the main steps of the chlorate process including the most important inputs and outputs as well as the internal loops.

whereof the major parts are salt purification and crystallization (Fig. 2). Environmental, health and economic reasons require a closed loop operation of the chlorate plants, which influences all parts of the process. This secures a high degree of recycling of chromium(VI) which minimizes its output. Different techniques for recycling the chromium are described in literature (see for example the Cyclochrome process in Ref. [25]). The closed loop operation however results in an accumulation of the impurities that enter the process via various raw materials. Hence the brine purification is an important and significant part of a chlorate production plant [26].

\section{The complex and manifold role of the chromium(VI) additive in the chlorate process}

The addition of chromium(VI) influences the process in many different ways, almost exclusively to its benefit. In this section the reported effects on the reactions at the cathodes, in the electrolyte bulk and at the anodes are described to provide a basis for the search for alternative substances.

\subsection{Film formation and its effect on the selectivity of the cathode process}

The most important effect of the chromium(VI) additive is that it increases the cathodic current efficiency of the chlorate process by hindering the reduction of oxy-chlorine species as hypochlorite and chlorate ions. During electrolysis chromium(VI) is reduced to $\mathrm{Cr}$ (III) on the cathode and forms a film of chromium(III)hydroxide according to Eq. (5).

$\mathrm{CrO}_{4}^{2-}+(4+n) \mathrm{H}_{2} \mathrm{O}+3 e^{-} \rightarrow \mathrm{Cr}(\mathrm{OH})_{3} \times n \mathrm{H}_{2} \mathrm{O}+5 \mathrm{OH}^{-}$

The film has poor electrical conductivity, contains high amounts of water and its composition has been determined as $\mathrm{Cr}(\mathrm{OH})_{3} \times \mathrm{nH}_{2} \mathrm{O}$ [27]. It hinders different cathodic reactions, among these the reduction of $\mathrm{Cr}(\mathrm{VI})$ and thereby its own growth, so after a period of electrolysis in a chromium(VI) containing electrolyte it reaches a final thickness $[28,29]$. The film is thin, less than $10 \mathrm{~nm}$ when formed in $1 \mathrm{M} \mathrm{NaOH}$, and its thickness depends on the substrate material, the electrolyte composition, the chromium(VI) concentration and the degree of cathodic polarization [29]. Experiments where a chromium hydroxide film was formed ex-situ and the electrode then transferred to a chromium (VI) free solution show similar results as for the in-situ formed films. Thus it is the film itself and not the dissolved chromium(VI) that accounts for the hindering effects [30-33].
Two different mechanisms have been proposed to explain this effect. According to one of the hypotheses chromium(VI) additions result in a porous diaphragm on the cathode surface, which negatively charged ions cannot penetrate due to the adverse potential gradient $[34,35]$. The other hypothesis explained the hindering effect by the formation of a thin film hindering certain reactions irrespective of the charge of the involved species $[32,36,37]$. Later results from further theoretical and experimental studies [28,38] supported this second hypothesis and also convincingly showed that the theory of the adverse potential gradient cannot be correct. The detailed mechanism through which the film hinders certain cathodic reactions is still not known but may be found in the properties of selective transport of different species through the film.

$\mathrm{OCl}^{-}+\mathrm{H}_{2} \mathrm{O}+2 e^{-} \rightarrow \mathrm{Cl}^{-}+2 \mathrm{OH}^{-}$

$\mathrm{ClO}_{3}^{-}+3 \mathrm{H}_{2} \mathrm{O}+6 e^{-} \rightarrow \mathrm{Cl}^{-}+6 \mathrm{OH}^{-}$

In the absence of chromium(VI) in the solution the two major cathodic loss reactions are the reduction of hypochlorite and chlorate ions, Reactions (6) and (7). While Reaction (6) is controlled by mass transport [39], Reaction (7) is kinetically controlled and its rate depends on the catalytic properties of the cathode material [40]. Chlorate reduction has been shown to be very fast on certain materials such as some oxides/hydroxides of iron [40] and ruthenium [41], whereas it is slow on cobalt, nickel, molybdenum, titanium, mercury and carbon [40]. A steel cathode covered by a thick, brown layer of iron oxides produced no visible hydrogen gas evolution when electrolyzing at an industrially relevant current density in chlorate electrolyte with no chromium (VI) addition [35]. Similar results were obtained for a ruthenium dioxide cathode [41]. Hydrogen evolved in both cases at a high current efficiency after addition of chromium(VI) to the electrolyte.

It has been shown that very low concentrations of chromium (VI), in the micromolar range, is sufficient to form a protective cathode film that hinders Reaction (6) on smooth steel and titanium [42]. Commercial sodium chlorate crystals typically contain up to $8 \mathrm{ppm} \mathrm{Cr}$, a concentration that will lead to over $90 \mu \mathrm{M}$ chromium(VI) in the electrolyte if preparing a $600 \mathrm{~g} \mathrm{dm}^{-3}$ $\mathrm{NaClO}_{3}$-solution. When studying alternative solutions to hinder Reactions (6) and (7) it is therefore important to analyze the chromium content of the chlorate salt and, if necessary, purify the crystals by e.g. recrystallization. On the other hand, on rough, catalytic surfaces much higher concentrations are needed to form a protective film. Corroded steel cathodes require higher chromium 
(VI) concentrations compared to smooth, non-corroded steel to obtain a high current efficiency in chlorate electrolyte [43].

In addition to Reactions (6) and (7) the chromium oxide/ hydroxide film hinders also the cathodic reduction of dissolved molecular oxygen [28,44], nitrate and nitrite ions [45] and hexacyanoferrate(III)[28]. Lindbergh et al. concluded that the suppression of the cathodic reaction was much more efficient for reactions involving adsorbed intermediates, as the reduction of hypochlorite and oxygen, than for simple outer-sphere reactions, such as the reduction of hexacyanoferrate(III) [28]. Kolthoff et al. studied several different cathodic as well as anodic reactions on a pre-filmed electrode [32]. The reduction of $\mathrm{Fe}(\mathrm{III})$ and the oxidation of $\mathrm{Fe}(\mathrm{II})$ were clearly hindered, whereas reduction of $\mathrm{Ag}(\mathrm{I})$ and of $\mathrm{Tl}(\mathrm{I})$ could easily proceed in the presence of the film. Yoshida et al. concluded that pre-filmed platinum electrodes were active for the hydrogen oxidation reaction (HOR) [46].

The chromium hydroxide film has recently found an application in photocatalytic water splitting, where $\mathrm{H}_{2}$ and $\mathrm{O}_{2}$ are formed on catalytic nanoparticles [47]. By coating the noble metal co-catalyst with a $\mathrm{Cr}$ (III) oxide/hydroxide layer (Fig. 3), the $\mathrm{O}_{2}$ reduction reaction is hindered. This significantly increases the efficiency of the water splitting process as the backward reaction of $\mathrm{H}_{2}$ and $\mathrm{O}_{2}$ forming $\mathrm{H}_{2} \mathrm{O}$ is inhibited [46-48]. The chromium containing layer was produced by photodeposition in $\mathrm{K}_{2} \mathrm{CrO}_{4}$ solution and was found to be a few $\mathrm{nm}$ in thickness [47]. The majority of the papers mentioned above suggest that selective permeability of different species through the $\mathrm{Cr}(\mathrm{III})$ oxide/hydroxide film is the reason for the increased cathodic current efficiency in its presence.

\subsection{The effect of the formed film on the kinetics of the hydrogen evolution reaction}

As opposed to the cathodic reduction of oxygen, hypochlorite species etc., hydrogen evolution can proceed on an electrode surface covered by the chromium oxide/hydroxide film. The reaction seems to take place at the interface between the film and the substrate $[46,49]$. Hydrogen ions and/or hydroxide ions can thus penetrate the film, which also contains large amounts of the reactant water. The product leaving the active sites is likely

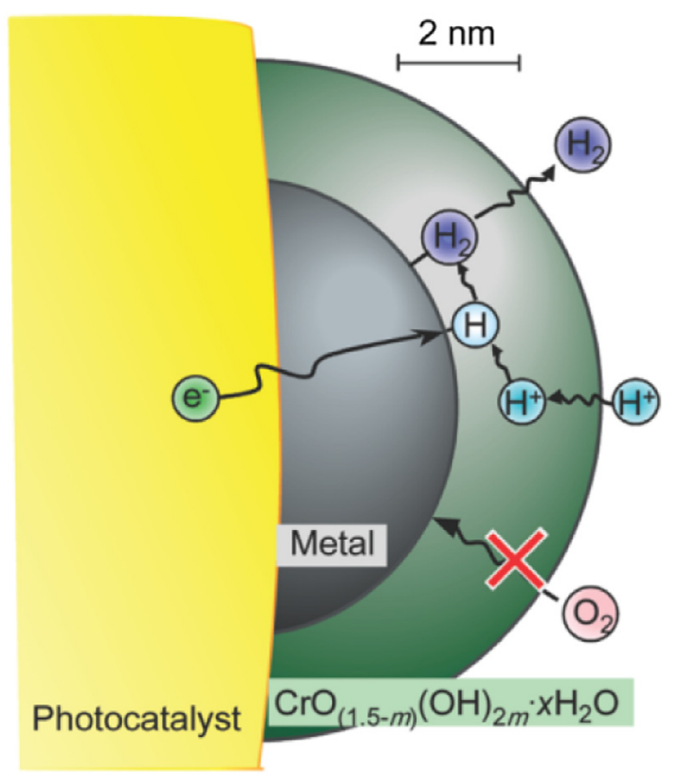

Fig. 3. Schematic model of the $\mathrm{H}_{2}$ evolution reaction on core/shell noble-metal/ $\mathrm{Cr}_{2} \mathrm{O}_{3}$ particulate system as a cocatalyst for photocatalytic overall water splitting [46]. molecular dihydrogen $\left(\mathrm{H}_{2}\right)$, which diffuses through the film to reach the free electrolyte [46].

The effect of the film on the kinetics of the electrochemical hydrogen evolution reaction (HER) for a steel cathode in chlorate electrolyte is difficult to interpret, as in the absence of the film the cathode reaction is a mix of hydrogen evolution and reduction of oxy-chlorine species (chlorate and hypochlorite ions). An increase in electrode potential of about $350 \mathrm{mV}$ at a constant current density observed for a steel cathode after addition of chromium(VI) to a chlorate electrolyte does therefore not represent changes in the HER kinetics [49]. Polarization curves recorded in sodium hydroxide electrolyte solution with and without the addition of chromium(VI) have shown that the presence of the chromium hydroxide film increases the rate of hydrogen evolution for poor electrocatalysts as $\mathrm{Au}$ [49] and $\mathrm{Pb}$ [50], whereas it decreases on electrocatalysts that are more favorable for hydrogen evolution, as rhodium [46], iron [49] and ruthenium dioxide [41]. As seen in Fig. 4., the Tafel slopes for the HER on a chromium hydroxide film covered $\mathrm{RuO}_{2}$ or Fe electrode are similar to those on the bare cathodes.

The Tafel slopes characteristic for the two materials are about $40 \mathrm{mV}$ decade ${ }^{-1}$ of current for $\mathrm{RuO}_{2}$ and $160 \mathrm{mV}$ decade ${ }^{-1}$ of current for Fe, irrespective of the presence of chromium(VI) in the solution. This indicates that hydrogen evolution takes place on active sites of the $\mathrm{RuO}_{2}$ or Fe substrate. A parallel shift of the polarization curves in the presence of chromium(VI) to more negative potentials indicates that the in situ formed film blocks a part of the active sites. Results from cyclic voltammetry [28] and in-situ IRAS [46] on Pt covered with chromium hydroxide films indicate that $75-80 \%$ and $80-90 \%$, respectively, of the Pt sites are still active for proton reduction.

For $\mathrm{Au}$ an activation of $100-200 \mathrm{mV}$ has been observed after addition of chromium(VI) to a $1 \mathrm{M} \mathrm{NaOH}$ electrolyte and the effect was obtained also on pre-filmed electrodes [49]. On Pb, which is a very poor HER catalyst, an overpotential decrease of over $200 \mathrm{mV}$ was found [50]. The activation observed indicates that the film must in this case be active in the hydrogen evolution reaction. Likely the reduction takes place at the innermost layer of the film, most possibly on chromium species as active sites.

\subsection{The influence of chromium(VI) on the chemical reactions}

Beyond the above mentioned very important role in increasing the cathode selectivity, chromium(VI) also plays a significant and complex role in the bulk chemistry. To fully understand this

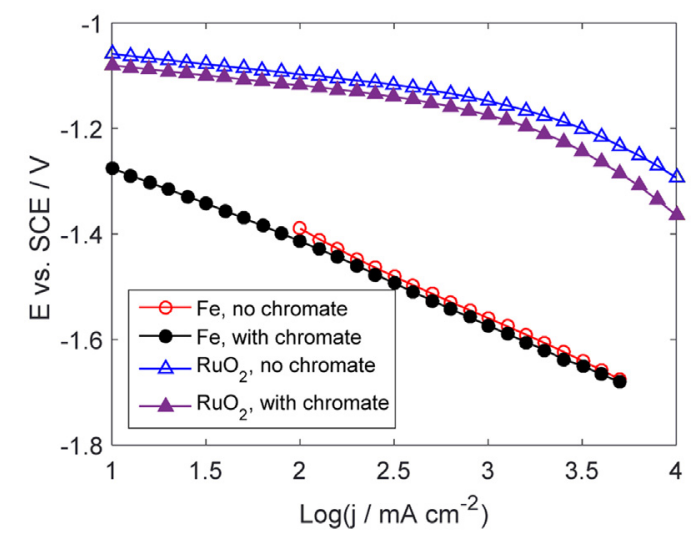

Fig. 4. Polarization curves of $\mathrm{Fe}$ and $\mathrm{RuO}_{2}$ electrodes in $1 \mathrm{M} \mathrm{NaOH}$ with and without $4 \mathrm{~g} \mathrm{dm}^{-3} \mathrm{Na}_{2} \mathrm{Cr}_{2} \mathrm{O}_{7}$ in the solution. Rotating disc electrodes, at $3000 \mathrm{rpm}$ rotation rate. 


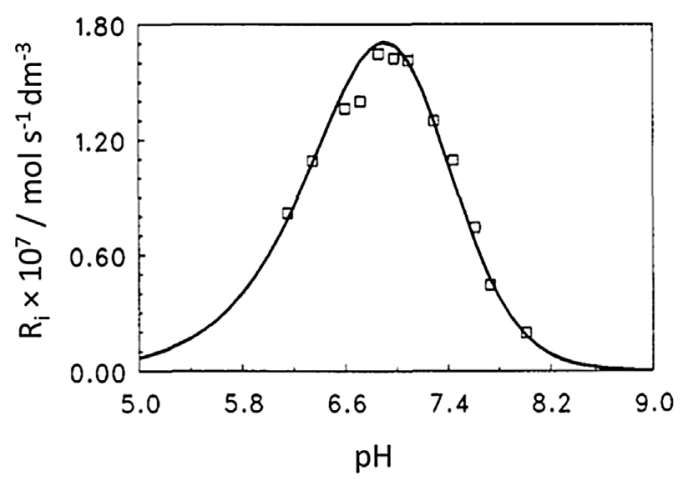

Fig. 5. Initial rate of hypochlorite decomposition, with $[\mathrm{HOCl}]_{0}=0.0233 \mathrm{M}$ at $\mathrm{T}=50^{\circ} \mathrm{C}$, determined with UV-vis spectroscopy [52].

complexity it is important to elaborate on the actual chlorate formation reactions and the properties of the electrolyte system.

\subsubsection{The homogeneous reactions of hypochlorite}

In the chlorate process (as detailed above), chlorine is formed from the oxidation of chloride on the anode. Chlorine is rapidly hydrolyzed forming hypochlorous acid and hypochlorite (and $\mathrm{HCl}$, according to Eq. (2)). In a subsequent disproportionation reaction the hypochlorite and hypochlorous acid form chlorate, as shown by Eq. (4). The chlorate formation is a slow reaction at room temperature but proceeds at a considerable rate at elevated temperatures like $80^{\circ} \mathrm{C}$. In weakly alkaline and acid solutions the reaction order for the chlorate formation approaches 3 [51,52]. The reaction rate is $\mathrm{pH}$ dependent and its maximum occurs when $[\mathrm{HOCl}] \approx 2\left[\mathrm{OCl}^{-}\right]$(Fig. 5), which is at $\mathrm{pH}=\mathrm{pK}_{\mathrm{a}}-0.3$, where $\mathrm{K}_{\mathrm{a}}$ is the acid dissociation constant of hypochlorous acid. The value of $\mathrm{pK}_{\mathrm{a}}$ is also dependent on the temperature and in a dilute solution, at $25^{\circ} \mathrm{C}$ it is reported to be 7.24 , while it equals to 6.98 at $70^{\circ} \mathrm{C}$ [23].

This is however not the only reaction pathway that hypochlorite can follow. An alternative reaction is the decomposition of hypochlorite which leads to unwanted oxygen as byproduct, as shown by the following reactions:

In the solution $2 \mathrm{HOCl} \rightarrow \mathrm{O}_{2}+2 \mathrm{Cl}^{-}+2 \mathrm{H}^{+}$

In the solution $2 \mathrm{OCl}^{-} \rightarrow \mathrm{O}_{2}+2 \mathrm{Cl}^{-}$

The decomposition of hypochlorite forming oxygen is a loss reaction causing both current efficiency losses as well as increased oxygen concentration in the hydrogen containing cell gas which is a safety issue. Fortunately this decomposition is slower than the concurrent chlorate formation reaction in the absence of catalysts. However, it is strongly catalyzed by impurities in the electrolyte such as $\mathrm{CO}^{\mathrm{II}}>\mathrm{Ni}^{\mathrm{II}}>\mathrm{Cu}^{\mathrm{II}}>>\mathrm{Fe}^{\mathrm{III}}>\mathrm{Mn}^{\mathrm{II}}$, given in order of catalyzing effect [53]. It is therefore of outmost importance to keep such catalysts out of the process. The rate of the decomposition reaction forming oxygen is also dependent on the $\mathrm{pH}$, and its maximum rate occurs in the same $\mathrm{pH}$ range in which chlorate formation has its optimum. Therefore it was suggested that the same reaction intermediate is involved in the formation of both chlorate and oxygen [23].

\subsubsection{Buffering effect of chromium(VI)}

The $\mathrm{HCrO}_{4}{ }^{-} / \mathrm{CrO}_{4}{ }^{2-}$ system has its maximal buffer capacity in the $\mathrm{pH}$ region 6-6.5, which coincides very well with the optimal $\mathrm{pH}$ of the chlorate formation reaction, see Fig. 5. The acid base equilibrium is described in Reaction (10) and its acid dissociation constant $\left(\mathrm{pK}_{\mathrm{a}, \mathrm{Cr}}\right)$ is reported to be in the range of 5.8-6.6 [54-57]. Hence its presence in the chlorate electrolyte promotes the chlorate formation.

$$
\mathrm{pK}_{\mathrm{a}, \mathrm{Cr}}=5.97\left(\mathrm{~T}=75^{\circ} \mathrm{C}, \mathrm{I}=5 \mathrm{M}\right) \quad \mathrm{HCrO}_{4}^{-} \rightleftharpoons \mathrm{CrO}_{4}^{2-}+\mathrm{H}^{+}
$$

$$
\lg \mathrm{K}_{\mathrm{d}}=1.46\left(\mathrm{~T}=75^{\circ} \mathrm{C}, \mathrm{I}=5 \mathrm{M}\right) \quad 2 \mathrm{HCrO}_{4}^{-} \rightleftharpoons \mathrm{Cr}_{2} \mathrm{O}_{7}^{2-}+\mathrm{H}_{2} \mathrm{O}
$$

In addition hydrogen chromate is in equilibrium with its dimer dichromate according to the dimerization Reaction (11) of which equilibrium constant is in the range of $\lg K_{d}=1.46-2.2$ [56-59]. In the distribution diagrams presented in Fig. 6 . it can be seen that the dominant chromium(VI) species in basic solution is chromate, $\mathrm{CrO}_{4}^{2}-$, while in the $\mathrm{pH}=3-6$ range hydrogen chromate ion, $\mathrm{HCrO}_{4}{ }^{-}$and the dimer, dichromate $\mathrm{Cr}_{2} \mathrm{O}_{7}{ }^{2-}$ dominate. The higher the chromium(VI) concentration the more relative amount of the dimer is formed.

Within the cell the $\mathrm{pH}$ is affected by the electrode reactions resulting in local $\mathrm{pH}$ gradients, as shown in Fig. 7A. The buffering effect of chromium(VI) (Fig. 7B) also influences these gradients. We note, that at very low pH (typically below 1 ) there is a risk of chlorine dioxide formation from the homogeneous reduction of chlorate by chloride [60-62]. Under normal operation conditions no chlorine dioxide is formed in the chlorate cell. However, without a buffer like chromium(VI), the electrolyte in the vicinity of the anode may reach acidities where chlorine dioxide formation can occur. In chlor-alkali membrane and diaphragm processes, which operate under much more acidic conditions, the chlorine dioxide formation from the byproduct chlorate is a known problem [63].

At the cathode hydrogen evolution can proceed via the reduction of protons or water molecules, as depicted in Reactions
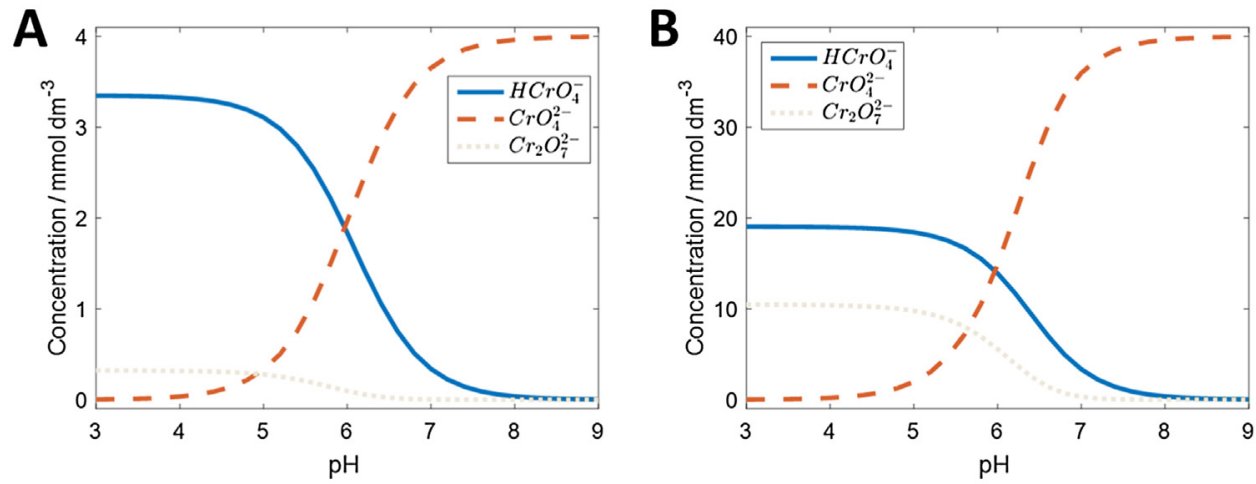

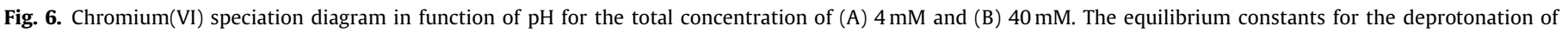
hydrogen-chromate and the dimerization process were taken to $\mathrm{pKa}=5.97$ and $\mathrm{Kd}=1.46$, as reported in [57] for the case of $\mathrm{I}=5.00 \mathrm{M} \mathrm{NaCl}$, $\mathrm{T}=75{ }^{\circ} \mathrm{C}$. 

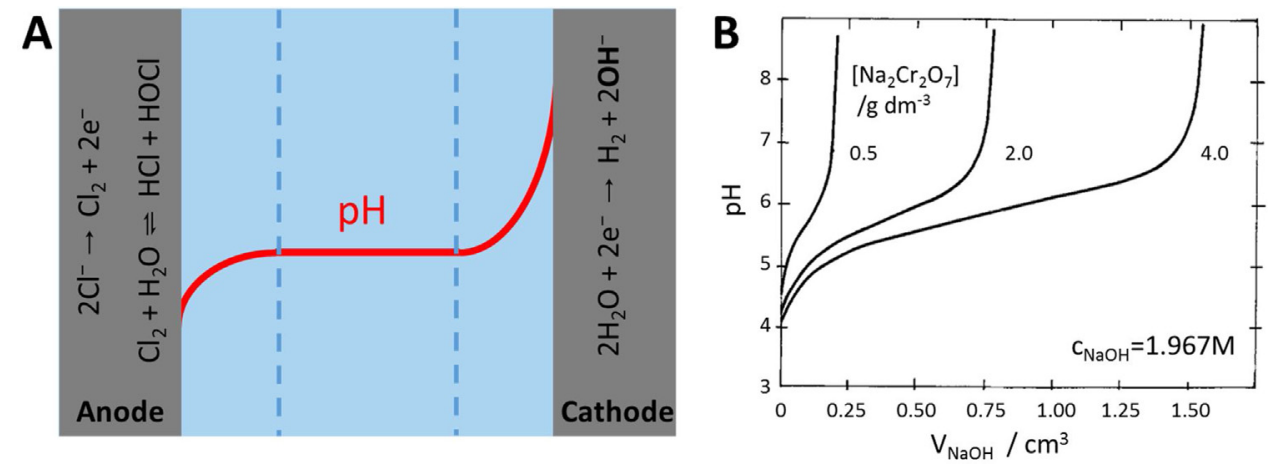

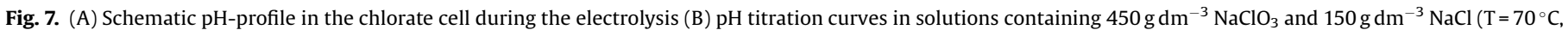
$\mathrm{V}=100 \mathrm{~cm}^{3}$ ) [35].

(12) and (13). At intermediate $\mathrm{pH}$, like in the chlorate process, Reaction (12) dominates at low current densities. As the current density is increased, and so the $\mathrm{pH}$ close to the cathode, a transition favoring the water reduction (Reaction (13)) takes place. This can be observed as a limiting current density for proton reduction, which depends on factors as mass transport and buffer capacity of the electrolyte. Experimental and simulated polarization curves for an iron RDE in chlorate electrolyte at varying dichromate concentration are shown in Fig. 8, and it is clearly seen that a higher concentration (and hence buffer capacity) results in a higher limiting current density for proton reduction [64].

$2 \mathrm{H}^{+}+2 e^{-} \rightarrow \mathrm{H}_{2}$

$2 \mathrm{H}_{2} \mathrm{O}+2 e^{-} \rightarrow \mathrm{H}_{2}+2 \mathrm{OH}^{-}$

As a consequence of above it is obvious that the $\mathrm{pH}$ of the electrolyte has a decisive role on both the electrochemical and the homogeneous chemical reactions. To achieve maximum current efficiency and plant safety the $\mathrm{pH}$ of the electrolyte is continuously monitored and adjusted to a narrow $\mathrm{pH}$ range during the operation. A variation in either direction will not only influence the rate of the chlorate formation reaction, it will also affect other factors such as desorption of chlorine and hypochlorous acid to the cell gas and the rate of oxygen evolution [62].

\subsubsection{Catalytic effect of chromium(VI)}

As elucidated before, it is well known that chromium(VI) in the chlorate process promotes the homogeneous chlorate formation reaction by buffering the electrolyte in the optimal $\mathrm{pH}$ range

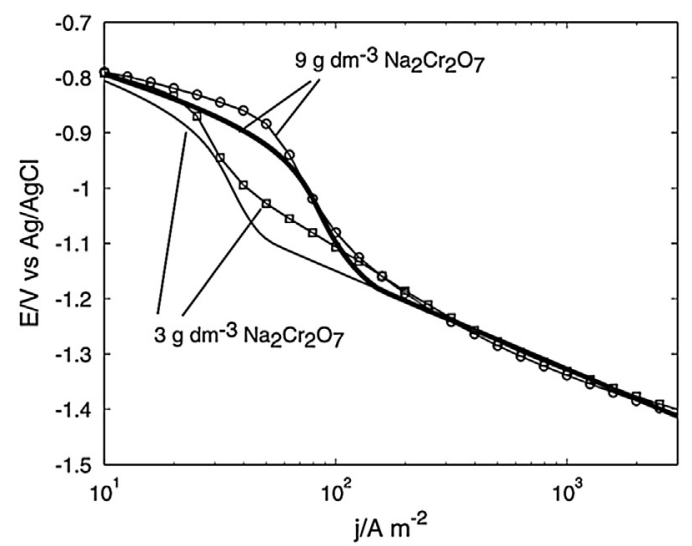

Fig. 8. Experimental (lines with symbols) and simulated (solid lines) polarization curves of an iron rotating disc electrode (at $3000 \mathrm{rpm}$ rotation rate), in chlorate electrolyte with 3 or $9 \mathrm{~g} \mathrm{dm}^{-3} \mathrm{Na}_{2} \mathrm{Cr}_{2} \mathrm{O}_{7}$ in the solution, at $\mathrm{pH}=6.5$ and $\mathrm{T}=70^{\circ} \mathrm{C}$ [64].
[12,35,65-67]. However, is the promoting effect of chromium(VI) a pure buffering effect or is there an additional catalytic effect? The catalytic effect of chromium(VI) on the chlorate formation reaction has been suggested $[65,68]$. On the other hand no catalytic effect was found in two other studies $[23,30]$. However none of them were conducted under conditions similar to the conditions in the chlorate process. Most recently the influence of chromium(VI) on the chlorate formation rate was investigated in chlorate electrolyte and a concentration dependent rate enhancing effect, likely catalytic, was demonstrated [68].

We note here that a decreased hypochlorite concentration in the chlorate electrolyte would lead to a decrease in the losses related to the unwanted side reactions of hypochlorite. It is therefore expected, that an additive which increases the rate of chlorate formation (without increasing the rate of oxygen formation) could increase the energy efficiency of the process and hence could have a significant contribution to the replacement of chromium(VI).

\subsection{Effect of chromium(VI) on the selectivity of the anode towards chlorine formation}

Oxygen is today the most important unwanted by-product in the chlorate process. It is formed in several reactions in the electrolyte bulk as well as on the anode (for descriptions of the reactions see the review by Karlsson et al. in ref [21]). At the anode oxygen has been suggested to be formed mainly from anodic reactions involving hypochlorite [69-71], or from the oxidation of water [40]. Fig. 9. shows the anodic current efficiency for active chlorine evolution, calculated based on analyses of oxygen in the cell gas, as a function of hypochlorite concentration. It is clearly seen that the current efficiency decreases linearly with hypochlorite concentration and a similar dependency has been reported in several other studies $[39,69]$.

The effect of chromate addition on oxygen formation is the subject of some controversy in the literature as an increase [66], a decrease [62,68] as well as no effect [69] have been reported. The deviation may be explained by the way the measurements were performed, as the system is complex and parameters as anode material, electrolyte composition and mass transport conditions can influence the results. In the study by Hardee et al. [69] it was emphasized that an increase in oxygen concentration in the cell gas in the absence of chromium(VI) can be due to a low cathodic current efficiency for hydrogen evolution. Even though the oxygen level increased in the cell gas in the absence of chromium(VI), the volumetric production of oxygen remained the same value.

Three ways in which chromium(VI) can influence the oxygen formation are through adsorption to active sites on the anode, by buffering the $\mathrm{pH}$ and by lowering the concentration of hypochlorite 


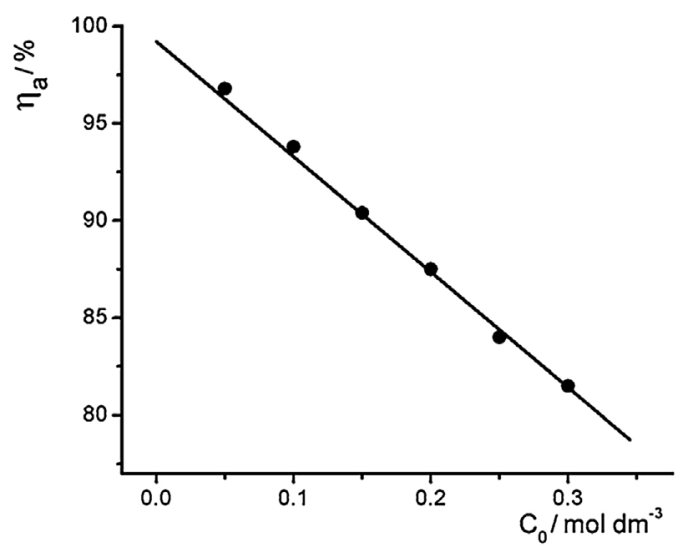

Fig. 9. Anodic current efficiency for active chlorine evolution as a function of the hypochlorite concentration in the solution (DSA anode, $300 \mathrm{~g} \mathrm{dm}^{-3} \mathrm{NaCl}, 2 \mathrm{~g} \mathrm{dm}^{-3}$ $\left.\mathrm{Na}_{2} \mathrm{Cr}_{2} \mathrm{O}_{7}, \mathrm{~T}=80^{\circ} \mathrm{C}\right)[71]$.

in the electrolyte. An increased anode potential has been observed for DSA-type anodes [72-74] and this has been explained by adsorption of chromium(VI) ions to active sites. Experiments at $\mathrm{pH}=2$, where buffer effects are negligible, resulted in a parallel shift of the polarization curve that indicated a decrease in active anode surface area [74]. The adsorption may promote oxygen forming reactions [66] and lead to a shorter lifetime of the anodes [72,73].

The $\mathrm{pH}$ in the vicinity of the anode surface is more acidic compared to that in the electrolyte bulk (Fig. 7A). This pH gradient is influenced by the buffer capacity of the electrolyte and thus by the chromium(VI) concentration. Reactions where oxygen is formed from hypochlorite ions, depend on $\mathrm{pH}$ which determines the ratio of the reactants $\mathrm{HOCl} / \mathrm{ClO}^{-}$[75].

The promoting effect of chromium(VI) on the chlorate formation (Reaction (4)) will lead to a lower hypochlorite concentration in the electrolyte at steady state operating conditions. As the anodic oxygen formation is directly proportional to the concentration of hypochlorite, see Fig. 9, an indirect effect of chromate addition is that it lowers the oxygen production through this mechanism [68].

More studies are needed to better understand the importance of the different effects of chromium(VI) on the $\mathrm{O}_{2}$ byproduct formation. In particular it would be valuable to analyze the oxygen production rate (rather than $\% \mathrm{O}_{2}$ in the cell gas) at varying chromium(VI) concentrations having a constant level of hypochlorite in the electrolyte.

\subsection{Effect of chromium(VI) addition on the corrosion of the cathode}

The most frequently used cathode material in the chlorate process is low-carbon steel. Although during the operation the electrode is cathodically protected, its corrosion cannot be overlooked during operational stops (e.g. service hours, maintenance). The chlorate electrolyte is highly corrosive and consequently the dissolution rate of the steel electrode can be fast, leading to frequent need of electrode replacement. Further, the corrosion products contaminate the chlorate product and can lead to short circuits in the narrow cell gaps. The rate of steel corrosion in a chlorate cell is determined by the limiting current for hypochlorite reduction, the cathode reaction in the corrosion process [76].

In studies regarding the corrosion of copper [44], steel [77], aluminum[78] or nickel [79], chromium(VI) is well-known of its inhibition properties, which is caused by the formation of a passivation chromium(III) oxide/hydroxide layer on the metal surface. Similarly, in the case of the steel cathode in the chlorate process, the film providing corrosion inhibition is a $\mathrm{Cr}(\mathrm{III})$ oxide/ hydroxide film. As long as the film stays on the electrode surface it protects the steel from corrosion by being a barrier for oxidants like oxygen and hypochlorite. However, during shut down on open circuit, this film is oxidized by hypochlorite in the solution [80] leaving the steel to corrode. Measurements of open circuit potentials on steel showed similar values irrespective of whether the electrolyte contained chromium(VI) [67], indicating that chromium(VI) does not inhibit corrosion to any large degree. If cathodic protection is used during shut down [62], the current needed to be applied depends on the concentration of chromium (VI), which reduces the rate of hypochlorite reduction [76]. Thus a lower current is sufficient in the presence of chromium(VI) compared to the chromium-free case.

In bipolar cells chromium(VI) can reduce the corrosion rate during production stops even at open circuit conditions. During shut down, the steel electrode starts to corrode, while oxychloric species are reduced on the DSA electrode. If the electrodes are connected (simulating the case of a chlorate cell setup with bipolar electrodes), the rate of these processes can be monitored by recording the appearing corrosion current, which is of reversed polarity as compared to that of the electrolysis process [81]. Addition of chromium(VI) to the electrolyte reduces these "reverse currents", thus hindering the corrosion process [43].

Although the corrosion of steel cathodes is an important problem in the chlorate process, the inhibiting property of the chromium(VI) additive is not of major concern when considering the chromium-free process.

\section{Suggested alternatives to chromium(VI) in the chlorate process}

Summarizing all the above detailed effects of the chromium(VI) additive in the chlorate process, one must admire how complex role it plays, and how perfectly its chemical properties fit in the process. It is therefore not surprising, that no single candidate has been found so far to replace it in all its functions. Despite of this, many promising steps have been taken in this direction. In the following sections, we summarize these earlier findings, directly related to the chlorate process. Moreover, relevant achievements of other research fields (photocatalytic water splitting, corrosion science) will be also briefly looked over. Note, that despite of the significantly different conditions, these fields share an important need for protected, selective catalytic surfaces. In photocatalytic water splitting hydrogen evolution should take place at a high rate from reduction of water while oxygen reduction should be avoided to achieve a high efficiency for hydrogen production. Suppression of the oxygen reduction reaction is also very important in corrosion science. Allied effort of these different communities may therefore open up research avenues to the mutual benefit of these fields.

With respect to the high investment cost and long lifetime of a chlorate plant a direct replacement of chromium(VI) to the electrolyte is seen as the preferred solution but also new electrode materials and completely new cell designs are considered.

\subsection{Alternative ways to maintain selectivity towards hydrogen evolution at the cathode}

\subsubsection{Addition of solution species}

4.1.1.1. Alkaline earth and rare earth metal salts. Among the earliest studies aiming for the energy efficiency improvement of the process, in situ formed diaphragms of alkaline earth metal hydroxides/carbonates were found to have beneficial effects [7]. This attempt was however shortly replaced by the more 
advantageous usage of dichromate additive, and therefore the scientific and industrial interest dedicated to additives of $\mathrm{Ca}$ (II) and $\mathrm{Mg}$ (II) salts diminished. This attempt was revisited and studied in more details almost a century after these first reports [82]. As found in this study, thick hydroxide films are formed on the cathode because of the increased $\mathrm{pH}$ level in the vicinity of the electrode (see Fig. 7A). Although the $\mathrm{MgCl}_{2}$ additive has insignificant effect on the current efficiency, the formation of a $\mathrm{Ca}(\mathrm{OH})_{2}$ layer leads to the suppression of the electrochemical reduction of hypochlorite. The thickness of the formed deposits is limited only by the mechanical erosion and by the $\mathrm{pH}$ gradient. Consequently these deposits can be in the range of couple hundred micrometers, or even millimeters thick and can therefore lead to blockage in the narrow cell gaps of about $3 \mathrm{~mm}$.

Very similarly, in situ formed cathode films of yttrium-, samarium- and lanthanum hydroxide can also suppress hypochlorite reduction on iron and gold in electrolytes of high ionic strength and elevated temperature. Addition of these salts were shown to activate the hydrogen evolution reaction. However a high chloride concentration ( $5 \mathrm{M} \mathrm{NaCl}$ ) was detrimental to the activating effect, in particular at elevated temperature. The low solubility of the rare earth metal ions in the chlorate electrolyte makes them unsuitable for industrial applications, and their use is therefore not a realistic alternative [83].

What is common in these two groups (alkaline earth and rare earth metals) is that the protective layer on the cathode is formed as a consequence of the increased local $\mathrm{pH}$. Its thickness, and morphology is therefore not controlled, it grows randomly during the electrolysis. We emphasize here, that one of the key success factor of the chromium(VI) additive is that the protective layer is formed in a Faradaic reaction, leading to a well-defined, thin compact coverage.

4.1.1.2. Chromium compounds with a valence state lower than +6. Chromium(III) chloride and similar compounds (e.g. $\mathrm{Cr}_{2} \mathrm{O}_{3}$ ), in which the valence state of chromium is lower than +6 have been suggested as an alternative by Hedenstedt et al. in a recent patent [84]. When adding such compounds to the chlorate electrolyte, its initially appearing blueish color almost instantaneously turns to dark orange, indicating the formation of $\mathrm{Cr}(\mathrm{VI})$ in the solution due to the oxidation of $\mathrm{Cr}$ (III) by hypochlorite. The addition of chromium(III) compounds circumvents the risks associated with the handling of sodium dichromate before addition to the electrolyte but chromium(VI) will be still present in the electrolyte and to some extent in the final product. This approach therefore cannot be considered as a long-term solution.

4.1.1.3. Molybdate. Molybdate has emerged as a promising alternative to chromium(VI) in the chlorate process $[42,85,86]$. During electrolysis, a $\mathrm{Mo} / \mathrm{MoO}_{\mathrm{x}}$ film is deposited on the electrode surface. In the case of a $\mathrm{Ti}$ cathode, in situ addition of $\mathrm{Mo}(\mathrm{VI})$ activated the HER in both alkaline and pH neutral electrolyte [86]. More importantly, the polarization curves for the HER were similar for titanium and molybdenum cathodes when molybdate was added to the solution. It was concluded that the formed film determines the electrocatalytic properties of the cathode. The film was significantly thicker than in the case of the chromium(VI), which indicates that the layer growth is not self-limited in this case.

Similarly to chromium(VI), molybdate also acts as a buffering agent during the chlorate process, according to the equilibrium shown in Eq. (14) [85]. It is worth mentioning however, that molybdate was found to buffer effectively in a lower and more narrow $\mathrm{pH}$ range than chromium(VI).

$\mathrm{pK}_{\mathrm{a}, \mathrm{Mo}} \approx 5-6 \quad \mathrm{HMoO}_{4}^{-} \rightleftharpoons \mathrm{MoO}_{4}^{2-}+\mathrm{H}^{+}$

To achieve current efficiencies matching the present industrial requirements, high concentration of molybdate needs to be added to the solution [42]. This leads to an increased overpotential and increased oxygen formation on the anode (Fig. 10). This is not only unfavorable for the overall energy efficiency of the process, but leads to severe safety concerns as explosive gas mixtures of $\mathrm{H}_{2}$ and $\mathrm{O}_{2}$ are formed.

Attempts were made to decrease the concentration of the molybdate additive and to increase the current efficiency by adding small amounts of chromium(VI) to the solution [42]. When adding both molybdate and chromium(VI) to the solution, an increase in the current efficiency was witnessed as compared to the cases when only one of the additives was used. Hence the same current efficiency could be achieved at a significantly lower chromium(VI) concentration.

\subsubsection{New electrode materials and electrode coatings}

4.1.2.1. Chromium containing cathode materials. The unwanted electrochemical reduction reactions on a stainless steel cathode can be effectively suppressed by plating a thin chromium metal film on it [87]. Although it has not been studied in detail, the reported significant weight loss of the electrode during electrolysis suggests, that the increased selectivity is caused by the two-step formation of a chromium(III) oxide/hydroxide film. As the first step the chromium metal is oxidized (and dissolved) by the hypochlorite formed in the solution. Subsequently, a chromium hydroxide film is deposited on the cathode that increases the current efficiency of the process.

In a recent study of Hedenstedt et al., $\mathrm{Cr}_{2} \mathrm{O}_{3}$ and $\mathrm{Cr}(\mathrm{OH})_{3}$ films were electrodeposited ex-situ, characterized and studied electrochemically in the presence of hypochlorite [33]. It was found that both layers hinder hypochlorite reduction, and the $\mathrm{Cr}_{2} \mathrm{O}_{3}$ is more active towards HER. It was proposed that semiconducting properties of the chromium film could be a reason for the selectivity of these films.
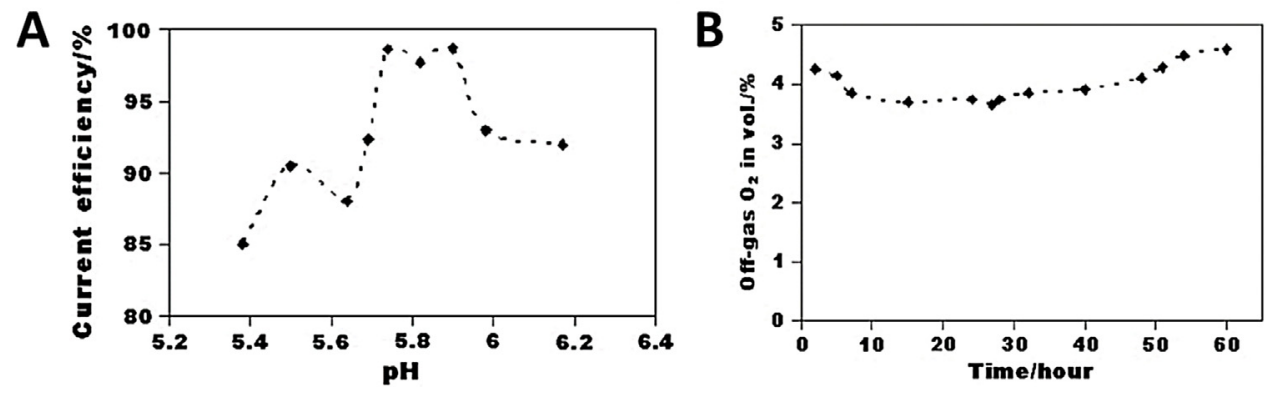

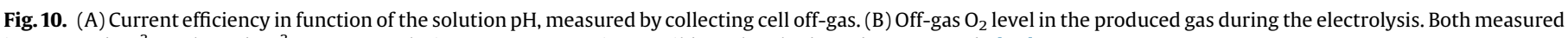
in a $300 \mathrm{~g} \mathrm{dm}^{-3} \mathrm{NaCl}, 8 \mathrm{~g} \mathrm{dm}^{-3} \mathrm{Na}_{2} \mathrm{MoO}_{4}$ solution at $\mathrm{T}=80^{\circ} \mathrm{C}$, using a mild steel cathode and a DSA anode [85]. 
Nanocrystalline coatings containing mixed oxides with different $\mathrm{Ti} / \mathrm{Ru} / \mathrm{Fe}$ atomic ratios were prepared by high-energy ball milling [88-90]. This approach leads to catalysts with high activity towards HER. Incorporation of chromium moieties - either in the form of $\mathrm{Cr}(0)$ or $\mathrm{Cr}_{2} \mathrm{O}_{3}$-in these catalyst resulted in a significant increase in the HER current efficiency when applied as cathodes in a chlorate electrolyte (as compared to the measurement with the chromium free electrodes, in the absence of chromium(VI)) [91]. The electrocatalytic activity of the catalysts for the HER was not influenced by the presence of the chromium species in the electrode. The analysis of the surface of this catalyst after electrolysis revealed the formation of a chromium-hydroxide film - similar in its chemical nature to the deposit formed when dichromate is added to the solution.

Although complete removal of chromium from the process is not achievable in these ways, and the long-term suppression of the side reactions have not been proven, these approaches are promising to significantly reduce the chromium content of the electrolyte and the sodium chlorate final product, and hence the handling risks.

4.1.2.2. Zirconium oxide. A detailed study has confirmed that zirconium oxide lowers the reduction rate of hypochlorite in $\mathrm{NaOH}$ solution [92]. Zirconium plates were oxidized in different ways, and the electrochemical activity and long-term behavior of the formed electrodes were compared. Although the thermally formed oxide showed a fairly high initial selectivity for the HER, it was shown that it ceases continuously during the electrolysis, which was attributed to the reduction of the layer. It was therefore concluded, that zirconium dioxide cannot be considered as an alternative electrode material in the chlorate production process [92].

4.1.2.3. Molybdenum containing electrodes and coatings. Fe-Mo alloys and $\mathrm{MoO}_{2}$ (with $\mathrm{MoO}_{3}$ traces on the catalyst surface) containing chromium $\left(\mathrm{Cr}-\mathrm{MoO}_{2}\right)$ electrodes were tested as cathodes for the electrochemical reduction of hypochlorite in neutral and slightly alkaline solutions, respectively $[93,94]$. In both cases, an increased activity towards the HER was found with the electrodes of optimized composition as compared to mild steel cathodes. In achieving high current efficiency however, the presence of a $\mathrm{Cr}(\mathrm{OH})_{3} / \mathrm{Cr}_{2} \mathrm{O}_{3}$ film on the electrode surface was crucial in both cases. The chromium(III) film formed during the electrolysis in the case of $\mathrm{Cr}-\mathrm{MoO}_{2}$ electrodes (through a similar mechanism as we discussed above for the chromium-plated electrodes), while addition of small amount $\left(0.1 \mathrm{~g} \mathrm{dm}^{-3}\right)$ of sodium dichromate to the used phosphate buffer was necessary in the case of the Fe-Mo alloy. Despite of this, the amount of the used chromium compound can be significantly reduced by these approaches.

4.1.2.4. Polymer coated chlorate cathodes. Polymer coatings, directly casted on the cathode, were considered to be possible alternatives in a patent by Tilak and co-workers [95]. Cathodes covered by perhalogenated polymeric materials (the chemical composition is not specified in the patent) showed similar current efficiencies to those with a thin $\mathrm{Cr}_{2} \mathrm{O}_{3}$ layer, close to $100 \%$ in chlorate containing electrolytes, at elevated temperature. Despite of these promising results, to the best of our knowledge no further patents or scientific articles were published on this topic, except for some very limited data [35].

\subsubsection{Selective HER catalysts in photocatalytic water splitting}

A selective catalyst for HER is desirable also in other applications such as photo(electro)chemical water splitting. The results and research strategies used might be therefore relevant also for solving the cathodic selectivity in the chlorate process. The reduction of atmospheric oxygen is an unwanted process during photo(electro)chemical water splitting as it leads to a lower overall efficiency. In addition, the products formed in the uncomplete reduction of $\mathrm{O}_{2}$ (e.g. radicals, hydrogen peroxide) cause the deactivation and leaching of the catalysts and degrade the supporting materials and the ionomers (e.g. the membrane in the water electrolyzers) as well, hence leading to shorter operational lifetime. To avoid this, several strategies have been proposed to suppress the oxygen reduction reaction, including the usage of different enzymes and molecular complexes [96]. While these avenues are unlikely to be suitable for the chlorate process, another branch of these studies, namely the application of oxygen tolerant catalytic surfaces may readily fit in the process.

As we already mentioned, the unwanted back-reaction in photochemical water splitting of $\mathrm{H}_{2}$ and $\mathrm{O}_{2}$ to $\mathrm{H}_{2} \mathrm{O}$ on the catalytic surfaces can be effectively suppressed by coating the active sites with a $\mathrm{Cr}$ (III) oxide/hydroxide layer [47]. Similar effect can be achieved by coating different photocatalysts with $\mathrm{NiO}$ [97], amorphous $\mathrm{TiO}_{2}$ [98], different lanthanide oxides [99], mixed amorphous Ti-Sn oxohydrates[100] and $\mathrm{SiO}_{2}$ [101]. Recently, ammonium tetrathiomolybdate was shown to increase the HER selectivity of gold surfaces at neutral pH [102]. In this case, the molybdate forms a couple $\mathrm{nm}$ thick, highly hydrated selfassembled layer, which prevents $\mathrm{O}_{2}$ to reach the surface (Fig. 11). This layer is also beneficial for the HER kinetics on the gold substrate.

The common in all these cases, is that the formed coverages preclude the $\mathrm{O}_{2}$ to reach the active catalytic sites, where $\mathrm{H}_{2}$ is formed. At the same time, the water splitting reaction can still proceed - either through the direct reduction of the water content of the highly hydrated films, or through an indirect mechanism, e.g. a ligand based proton coupled electron transfer process [102]. We highlight, that except for the chromium films, none of these compounds have to the best of our knowledge been tested in the chlorate process.

\subsubsection{Corrosion protection layers with oxygen reduction hindering properties}

The corrosion rate of metals can be moderated by suppressing the rate of the metal oxidation and/or the coupled reduction reaction, which is most typically the reduction of atmospheric oxygen. A high scientific interest is therefore dedicated to find

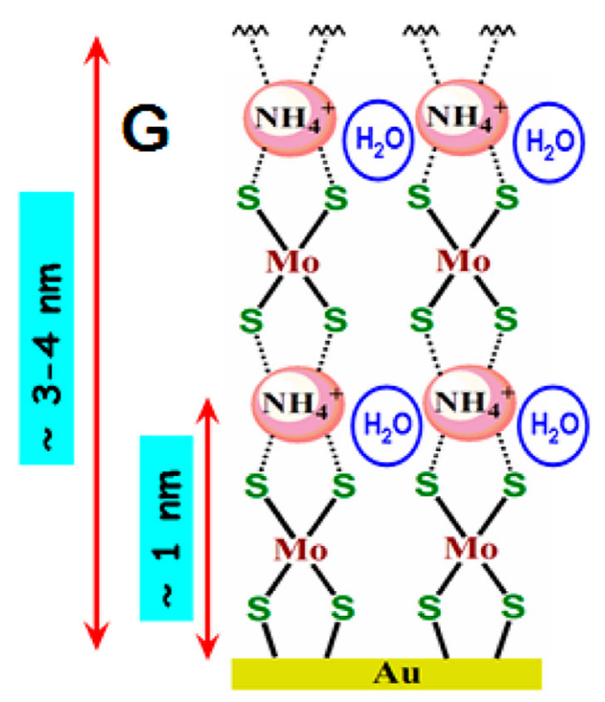

Fig. 11. Schematics of the vertical cross section of a probable three-dimensional ammonium tetrathiomolybdate assembly on an Au electrode [102]. 
solutions to the suppression of this latter process. One solution for this is to cast protective layers on the otherwise corroding substrates, preventing the oxygen to reach the metal surface. Similar chromium compounds which ensure the high current efficiency of the chlorate process are very frequently used as corrosion protection layers [44,77-79].

The desire to protect metal surfaces from corrosion dates back as early as Mankind started using different metals, and therefore a very significant knowledge has been treasured in this field $[103,104]$. Suggested alternatives to chromium for effective corrosion protection are for example rare-earth metal compound coatings [105], sol-gel formed zirconates and titanates [106], Cebased coatings[107] or even layered double hydroxides [108]. The use of organic coatings (e.g. polyesters or polyurethanes) represent another significant class of these studies [109]. In most cases these layers serve as a physical barrier between the metal surface and oxygen. This property makes these materials attractive candidates for chlorate cathodes, but we emphasize, that several other requirements, most importantly high HER activity, must be also met.

\subsubsection{Application of new cell designs in chlorate production}

Physical separation of the oxychloride products, formed on the anode and in the subsequent chemical reactions in the solution, may be the ultimate solution to circumvent their unwanted reduction on the cathode. Important to remember that in all such applications there will be a need to control $\mathrm{pH}$ and water balance, which is already a part of an optimized undivided cell. Also note, that changing from undivided to separated electrochemical cells would require a major investment from the industrial participants and a long optimization process. Therefore this route is considered as a long-term alternative to the current technology.

4.1.5.1. Ion-exchange membrane separated chlorate cell. Including an ion-exchange membrane between the anode and the cathode chambers leads to the complete inhibition of the unwanted reduction of chlorate and hypochlorite. It can be envisioned, that such a process can be operated with an inherently high current efficiency without the addition of chromium(VI). Further, remarkable development of membranes in the sense of conductivity, physical and chemical resistivity and temperature tolerance may make it possible to separate the electrodes without causing a striking decrease in the energy efficiency of the process $[110,111]$.

A divided-cell setup with an anion-exchange membrane separator was tested in the electrochemical hypochlorite production [112]. Solutions of different chloride and hypochlorite concentrations were electrolyzed at a constant current density, and the current efficiency was monitored by both volumetric analysis of the gaseous products and potentiometric titration of the formed chlorine derivatives. The most important findings of this study was that the overall current efficiency of the cell is dictated only by the anodic losses $\left(\mathrm{O}_{2}\right.$ formation from $\mathrm{H}_{2} \mathrm{O}$ and hypochlorite oxidation), the parasitic cathode reactions are completely circumvented by the application of the membrane. Using an anionexchange membrane separated cell is in principle an optimal idea, realizing the needed ion transport, but - according to the best of our knowledge - until now no anion-exchange membrane is available with sufficient stability against alkaline and oxidizing conditions.

Cation-exchange membrane separated cells are extensively applied in the chlor-alkali process (schematics of the cell is depicted in Fig. 12.). In such cells the used membranes show good selectivity and long-term stability. Although the conditions $(\mathrm{pH}, \mathrm{T}$, electrolyte concentration) of the chlorate process are different from that of the chlor-alkali production, the solution species present, and the consequent oxidative nature of the electrolyte is very similar in the two cases. Therefore, the stability of the membranes used in the chlor-alkali production is promising for their use also at chlorate process conditions.

4.1.5.2. Membrane separated chlorate cells with oxygen depolarized cathodes. Another possibility to increase the energy efficiency of the chlorate process is to change the cathode reaction from hydrogen evolution to a thermodynamically and/or kinetically more favored reaction on the cathode and hence decrease the cell voltage.
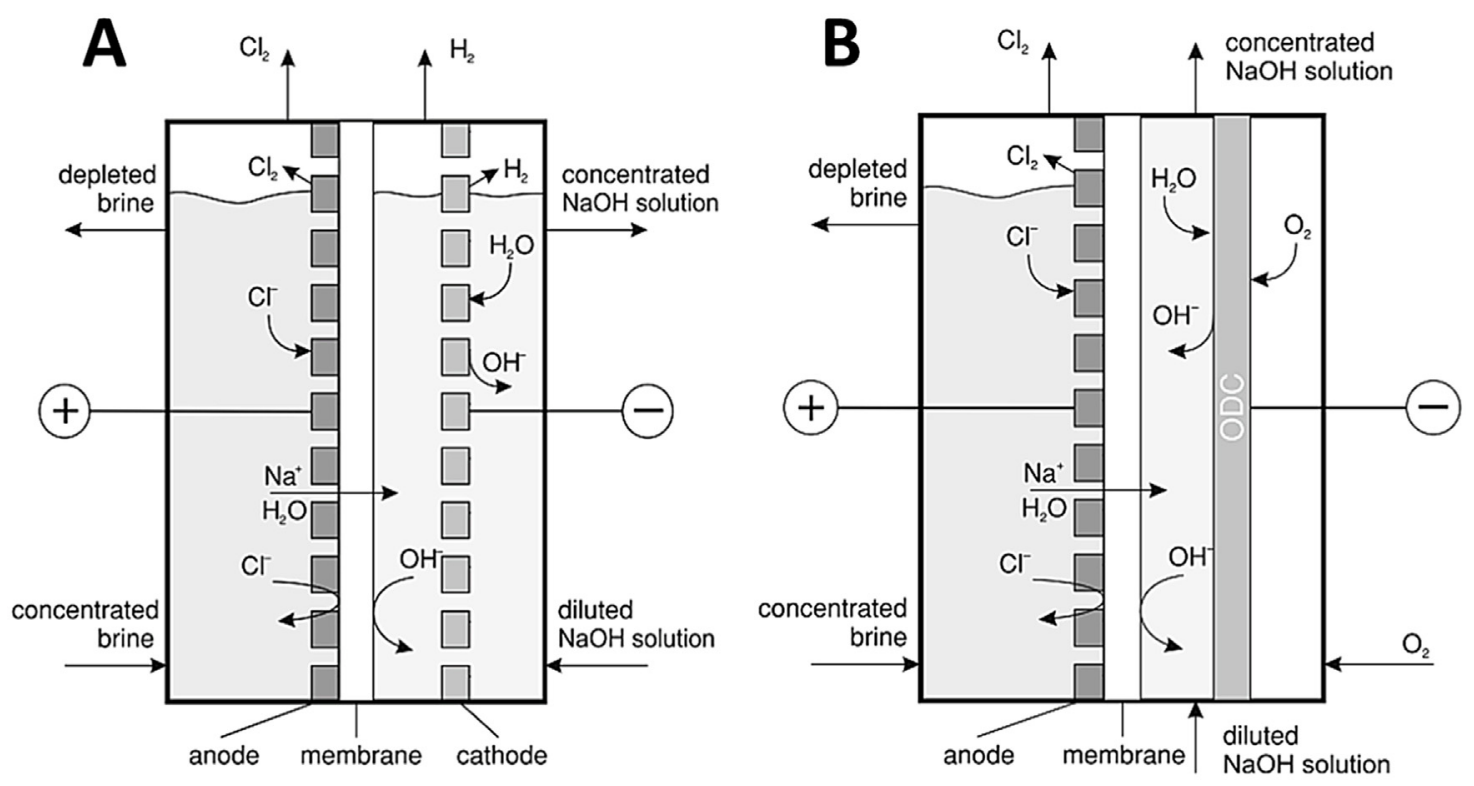

Fig. 12. Comparison of chlor-alkali electrolysis in a membrane separated electrolysis cell with (A) hydrogen evolving and (B) oxygen depolarized cathodes [113]. 
Table 2

Effect of formerly investigated catalysts on the decomposition rate of hypochlorite (N.A.: not analyzed, RT: room temperature)

\begin{tabular}{|c|c|c|c|c|c|c|c|c|c|}
\hline \multirow[t]{2}{*}{ Solution composition } & \multirow[t]{2}{*}[\mathrm{OCl}^{-}]{$_{0} / \mathrm{M}$} & \multirow[t]{2}{*}{$\mathrm{T} /{ }^{\circ} \mathrm{C}$} & \multirow[t]{2}{*}{$\mathrm{pH}$} & \multirow[t]{2}{*}{ Catalyst } & \multirow[t]{2}{*}{ Catalyst amount } & \multicolumn{3}{|c|}{ Effect on the rate of } & \multirow[t]{2}{*}{ Ref. } \\
\hline & & & & & & $\mathrm{HOCl}$ decomp. & $\mathrm{ClO}_{3}{ }^{-}$formation & $\mathrm{O}_{2}$ evolution & \\
\hline $0.32 \mathrm{M} \mathrm{NaOH}+\mathrm{NaCl}$ & $0.8-1.4$ & $30-60$ & Alkaline & $\begin{array}{l}\text { Mn, Fe oxide } \\
\text { Co, Ni, Cu oxide }\end{array}$ & $1.5-5 \mathrm{mg} \mathrm{dm}^{-3}$ & + & $\begin{array}{l}\text { No/negligible effect } \\
\text { No effect }\end{array}$ & + & [53] \\
\hline$\sim 2 \mathrm{M} \mathrm{NaCl}+\mathrm{NaOH}$ & $0.8-1.6$ & $30-60$ & Alkaline & Ionic strength & & + & N.A. & N.A & [121-123] \\
\hline $2 \mathrm{M} \mathrm{NaCl}+\mathrm{NaOH} /$ Buffers & 0.136 & $20-40$ & $7-11$ & $\mathrm{Na}_{2} \mathrm{IrCl}_{6}$ & $1-7 \mathrm{mg} \mathrm{dm}^{-3}$ & + & $+($ neutral $)$ & $(+)$ (alkaline) & {$[124,125]$} \\
\hline$\sim 1 \mathrm{M} \mathrm{NaCl}$ & $\sim 1$ & 25 & Alkaline & $\begin{array}{l}\mathrm{Ni}, \mathrm{Co} \text { peroxide } \\
\mathrm{Cu}(\mathrm{OH})_{2} \\
\mathrm{Al}, \mathrm{Fe}, \mathrm{Mn}, \mathrm{Hg} \text { oxide }\end{array}$ & $0.02-2 \mathrm{~g} \mathrm{dm}^{-3}$ & $\begin{array}{l}+ \\
(+) \\
\text { Negligible effect }\end{array}$ & $\begin{array}{l}\text { N.A. } \\
\text { N.A. }\end{array}$ & $\begin{array}{l}+ \\
(+)\end{array}$ & [126] \\
\hline $1.14 \mathrm{M} \mathrm{NaCl}+0.28 \mathrm{M} \mathrm{NaOH}$ & 1.14 & $25-50$ & Alkaline & Co peroxide & $\mathrm{mM}$ range & + & N.A. & + & [127] \\
\hline$\sim 2 \mathrm{M} \mathrm{NaCl}$ & $\sim 2 \mathrm{M}$ & $40-70$ & Alkaline & $\mathrm{Cu}(\mathrm{II})$ & $1-2 \mathrm{ppm}$ & + & N.A. & + & [128] \\
\hline $0.05-0.1 \mathrm{M} \mathrm{NaOH}$ & $0.4-0.8$ & $30-45$ & Alkaline & $\begin{array}{l}\text { Cu, Fe oxide } \\
\text { Cu oxide }\end{array}$ & $50-250 \mathrm{mg} \mathrm{dm}^{-3}$ & $\begin{array}{l}+ \\
+\end{array}$ & $\begin{array}{l}\text { N.A. } \\
\text { N.A. }\end{array}$ & $\begin{array}{l}+ \\
+\end{array}$ & {$[129,130]$} \\
\hline & & RT & & MgO promoted $\mathrm{Cu}$ oxide & $20-400 \mathrm{mg} \mathrm{dm}^{-3}$ & + & N.A. & + & [131] \\
\hline $0.3-0.7 \mathrm{M} \mathrm{NaCl}$ & $0.3-0.7$ & 25 & $7-11$ & Co-oxide & $2 \mathrm{gdm}^{-3}$ & + & $(+)$ neutral & + & [132] \\
\hline Dilute aqueous solution & $310 \mathrm{ppm}$ & RT & No inf. & $\begin{array}{l}\text { Fe oxide-hydroxide } \\
\text { Cu oxide-hydroxide }\end{array}$ & $1.67 \mathrm{~g} \mathrm{dm}^{-3}$ & $\begin{array}{l}\text { No effect } \\
(+)\end{array}$ & N.A. & N.A. & [133] \\
\hline & & & & $\mathrm{Ni}$, Co oxide-hydroxide & & + & N.A. & N.A. & \\
\hline $0-4 \mathrm{M} \mathrm{NaOH}$ & $\sim 0.2$ & 25 & Alkaline & $\mathrm{Cu}(\mathrm{OH})_{2}$ & $10-100 \mu \mathrm{M}$ & + & N.A. & + & [134] \\
\hline Dilute aqueous solution & $\min .5 \%$ & 75 & Alkaline & $\begin{array}{l}\mathrm{MnO}_{2} \\
\mathrm{CuO}\end{array}$ & $\begin{array}{l}1 \mathrm{w} / \mathrm{v} \% \\
1 \mathrm{w} / \mathrm{v} \%\end{array}$ & $\begin{array}{l}\text { No/negligible eff } \\
+\end{array}$ & ect & $\mathrm{N} A$ & [135] \\
\hline $\mathrm{NaCl}+\mathrm{NaOH}$ & $\sim 1$ & RT & Alkaline & $\begin{array}{l}\mathrm{Cr}, \mathrm{Fe}, \mathrm{Mn}, \mathrm{U}, \mathrm{Bi}, \mathrm{Pd}, \mathrm{Os}, \mathrm{Ta}, \mathrm{V} \text { oxide } \\
\text { Co, Ni, Ir oxides }\end{array}$ & $\begin{array}{l}0.1 \mathrm{~g} \mathrm{dm}^{-3} \\
0.1 \mathrm{~g} \mathrm{dm}^{-3}\end{array}$ & $\begin{array}{l}\text { No/negligible eff } \\
+\end{array}$ & ect & N. A. & [136] \\
\hline Dilute aqueous solution & $80 \mathrm{mM}$ & 80 & 6.5 & $\begin{array}{l}\mathrm{FeCl}_{3}, \mathrm{Fe}_{3} \mathrm{O}_{4}, \mathrm{CeCl}_{3}, \mathrm{Na}_{2} \mathrm{Cr}_{2} \mathrm{O}_{7}, \mathrm{Na}_{2} \mathrm{MoO}_{4}, \mathrm{RuCl}_{3}, \mathrm{RuO}_{2} \\
\mathrm{AgCl} \\
\mathrm{Al}_{2} \mathrm{O}_{3} \\
\mathrm{CoCl}_{2} \\
\mathrm{IrCl}_{3}\end{array}$ & $\begin{array}{l}10 \mu \mathrm{M} \\
100 \mathrm{ppm} \\
9 \mathrm{ppm} \\
10 \mu \mathrm{M} \\
10 \mu \mathrm{M}\end{array}$ & $\begin{array}{l}\text { No/negligible eff } \\
\text { No/negligible eff } \\
\text { No/negligible eff } \\
+ \\
+\end{array}$ & $\begin{array}{l}\text { ect } \\
\text { ect } \\
\text { No effect } \\
+\end{array}$ & $\begin{array}{l}+ \\
+\end{array}$ & [23] \\
\hline
\end{tabular}


Following this thread, a specific variant of the membrane separated cell can be envisioned by utilizing a porous electrode as the cathode, which is continuously fed with pressurized, oxygen containing gas (Fig. 12B). Application of this oxygen depolarized cathode concept leads to a large reduction in the chlor-alkali cell voltage [113]. We note that this is not only supported by academic studies, but plant(s) working on this principle have already been built and are in operation [114]. Although several studies have addressed the applicability of such devices also for chlorate production, $[115,116]$ their industrial application has still not been realized. The most important reasons for this are the requirement of continuous, pressurized oxygen feeding (the purity is also an important factor), and that the $\mathrm{H}_{2}$ produced in the "original" chlorate process is in many cases a valuable product which is not produced here. Further, in the incomplete reduction of oxygen $\mathrm{H}_{2} \mathrm{O}_{2}$ may be formed, which may degrade both the catalyst and the applied porous substrate, and could lead to the intense formation of oxygen in the cell. Also, precipitation of sodium peroxide may occur in the cell, leading to the blockage of both the active surface area of the catalyst, and the pores of the gas diffusion electrode $[113,117]$.

As another promising example, a very similar setup can be used for the reduction of $\mathrm{CO}_{2}$ during chlorine production [118]. By finetuning the reaction parameters (e.g. catalyst, flow-rate, temperature etc.), a simultaneous production of synthesis gas $\left(\mathrm{CO}-\mathrm{H}_{2}\right.$ mixture) on the cathode, and chlorine formation on the anode can be achieved. As important raw chemicals are formed on both electrodes, such cells can be important units in a well-integrated commodity chemical synthesis plant. As a further added-value, a harmful greenhouse-gas, $\mathrm{CO}_{2}$ is consumed in the process.

4.1.5.3. Chlorate formation from chlorine gas and caustic soda produced in a chlor-alkali plant. State-of-the-art membrane separated chlor-alkali plants produce chlorine at a power consumption of $2100-2600 \mathrm{kWh} \mathrm{t}^{-1} \quad \mathrm{Cl}_{2}$ [119]. Using this chlorine for the chemical production of $\mathrm{NaClO}_{3}$ in an external reactor, the specific power consumption can be calculated to this latter (considering the stoichiometry of the chlorine disproportion reaction and the chemical chlorate formation reaction, as depicted in Eqs. (2) and (4)) to be $5000-5500 \mathrm{kWh} \mathrm{t}^{-1} \mathrm{NaClO}_{3}$. This energy consumption is fairly comparable to the energy need of chlorate formation in the currently applied undivided electrochemical cells. In this case, however, no chromium(VI) needs to be added for current efficiency reasons, leading to the complete diminishment of the safety hazards related to its handling. Further, the produced chlorate is free of any chromium(VI) contamination. Also note, that in the case of the chlor-alkali cell very pure $\mathrm{H}_{2}$ (>99.9\%), with low oxygen and chlorine content is produced on the cathode. This is of higher value than the gas mixture formed in the case of the actual chlorate process, contributing to the economic feasibility of this concept [120].

$$
3 \mathrm{Cl}_{2}+6 \mathrm{NaOH} \rightarrow 5 \mathrm{NaCl}+\mathrm{NaClO}_{3}+3 \mathrm{H}_{2} \mathrm{O}
$$

Reaction (15) illustrates the overall chemical reaction taking place outside of the electrochemical reactor. As seen, five chloride ions are formed for each chlorate ion. The formed chloride needs to be recycled to the cells, whereas chlorate should be separated as the product of the process. It is of high importance that the recycled chloride stream does not contain any chlorate that could form chlorine dioxide in the acidic anolyte. Another concern about this concept, is that for the available membranes the concentration of the caustic soda is limited to $32 \mathrm{wt} \%$. Using this for chlorate production (according to Eq. (15)) the achievable chlorate concentration is not high enough for crystallization. The solution must therefore be concentrated e.g. by evaporating a significant portion of the solvent, while water must be fed to the cathode compartment, leading to considerable additional costs.

\subsection{Catalysis of the homogeneous chlorate formation reaction}

The concentration of hypochlorite has a significant impact on the energy efficiency of the chlorate process as it influences both the anode and the cathode reactions as explained in the previous sections. Finding a catalyst which selectively increases the rate of chlorate formation is highly desired. It would lead to lower steadystate concentrations of hypochlorite in the chlorate solution, thus less oxygen produced, and possibly to more efficient process designs as smaller reactor volume (see Fig. 2) would be needed for the chlorate forming reaction. Several studies were conducted to identify the effect of different compounds on the decomposition rate of hypochlorite and on the oxygen formation rate, as summarized in Table 2 .

Several transition metal derivatives, e.g. $\mathrm{CuO}$, Co-oxide, $\mathrm{Ni}-$ oxide were shown to catalyze the decomposition of hypochlorite to oxygen, without having significant effect on the chlorate formation. Other compounds, e.g. $\mathrm{MnO}_{2}$, Fe-oxides were shown to have no effect on the decomposition rate of hypochlorite. More importantly, only iridium-salts were found to catalyze the formation of chlorate $[23,124,125]$. The presence of chromium (VI) was shown to have no effect on neither the chlorate nor the oxygen formation rate in dilute, neutral/alkaline hypochlorite solutions $[23,30,136]$.

It is important to highlight, however, that none of these measurements were performed under the circumstances (solution composition, temperature, $\mathrm{pH}$ ) of the actual chlorate process. Therefore these results must be handled with precautions, and should be repeated at industrially more relevant conditions.

\subsection{The use of alternative buffers in the chlorate process}

The buffering effect of the chromium(VI) additive is crucial for the chlorate process. The solution $\mathrm{pH}$ has a significant impact on the homogeneous chlorate formation rate, and hence on several different aspect of the process, e.g. on the oxygen production rate, as described in the previous sections [52]. In solutions with no chromium(VI) addition, the decreased buffer capacity may necessitate the addition of some buffering agent.

The applicability of phosphate buffer has been studied $[42,66,94]$. These studies concluded, that in a membrane separated electrochemical cell the cathode current efficiency is slightly increased. In parallel with this, an increased $\mathrm{O}_{2}$ production rate was witnessed on the anode, possibly caused by the specific adsorption of the phosphate ions. The phosphate was also identified as an anode poison by anode producers [137]. Another specific problem in the existing chlorate process is the formation of stable precipitates between phosphate and di- or trivalent cations such as $\mathrm{Ca}^{2+}$ and $\mathrm{Fe}^{3+}$ [138]. In contradiction to this Spasojevic and his co-workers found, that partial replacement of chromium(VI) with the phosphate buffer is beneficial for the anode current efficiency for certain anode coatings [65,139].

\section{Conclusions and future outlooks}

Chromium(VI) serves several roles in the chlorate production and has an effect on almost every sub-step of the process, ranging from the electrode reactions to the buffering of the solution. Most important of these is the increased current efficiency, ensured by the suppression of the unwanted electrochemical processes on the cathode. This originates from the formation of a coherent, compact, thin film of $\mathrm{Cr}(\mathrm{III})$ hydroxide with poor conductivity. This layer is permeable for the reactant $\left(\mathrm{H}_{2} \mathrm{O} / \mathrm{H}^{+}\right)$and the reduction products 
$\left(\mathrm{H}_{2} / \mathrm{OH}^{-}\right)$, but not for other compounds e.g. chlorate ions, hypochlorite or even molecular oxygen. When compared to other suggested film forming additives, such as alkaline earth metal salts, the main difference is that the $\mathrm{Cr}$ (III) hydroxide film is preceded by an electrochemical reduction step, leading to a layer on the cathode with a well-controlled structure. Furthermore, the coherent coverage and its low electrical conductivity hinders further reduction of chromium(VI), and hence limits the thickness of the film. Whenever this protective layer is damaged (e.g. by mechanical erosion, chemical dissolution during operational stops), it is quickly re-formed during electrolysis. As it is very thin, the IR-drop over the film during operation is rather low.

Chromium is stable in dissolved form in its highest oxidation state (VI) in the solution in a wide $\mathrm{pH}$-range, ensured by the strong oxidizing nature of the chlorate electrolyte. Thus, it does not precipitate in the alkaline conditions at the cathode and in the crystallizer or in the acidic region close to the anode. In addition to this, the buffering effect and promotion of the chemical chlorate formation leading to a lower hypochlorite concentration and thereby less anodic oxygen are also beneficial for the chlorate process. When aiming to replace chromium(VI) in the process, one must therefore consider several different technological aspects.

Today there is no way to efficiently run chlorate electrolysis without the addition of chromium(VI). As the role of this additive is very complex, it is highly unlikely to find a single solution for all its functions. Instead a combined effect of different modifications may lead to the solution. A fundamental understanding of each function of chromium(VI) will facilitate finding its replacement. Of highest importance is the selectivity of the cathode, which may be solved either by using membrane separated cells or by developing a selective cathode material - either formed ex situ, or in situ during the electrolysis from a solution additive, similar to chromium(VI). A similar problem with cathodes, selective for hydrogen evolution is found in the research intensive area of photochemical water splitting, where oxygen reduction is to be avoided while hydrogen evolution should take place at a high rate. Solutions found here may be applicable also in the chlorate process - and vice versa. Another nearby area is corrosion protection, where various film forming compounds have been suggested to replace chromium(VI) in its function to hinder the cathodic reaction of oxygen reduction in the corrosion process. Thus, following the progress in these areas may be fruitful in the development of a chromium-free chlorate process.

An alternative buffer is needed in a chromium-free process running at close to neutral $\mathrm{pH}$. It is not clear whether chromium (VI) has a catalytic effect on the chlorate forming reaction, or its promotion is solely due to buffering effect. Nevertheless, a catalyst that selectively catalyzes the homogeneous chlorate formation could lead to new, more efficient process designs as a faster reaction would require less volume for the external chlorate crystallization step. There are very few studies in the literature on catalyzed hypochlorite decomposition at conditions relevant to industrial chlorate production, and more research is needed to better understand the reaction and how its rate can be selectively enhanced.

Combined efforts from several competence fields such as electrochemistry, electrochemical engineering, chemical reaction kinetics, materials chemistry and (chlorate) process technology is necessary to find a solution to the urgent and complex problem of chromium(VI) replacement.

\section{Acknowledgements}

Financial support from the Swedish Energy Agency and AkzoNobel Pulp and Performance Chemicals is gratefully acknowledged. We would like to thank the anonymous reviewers for their thorough revision and valuable suggestions on the former version of the manuscript.

\section{References}

[1] IPTS/EC, Integrated Pollution Prevention and Control Reference Document on Best Available Techniques for the Manufacture of Large Volume Inorganic Chemicals - Solids and Others Industry. Brussels, Belgium, 2007.

[2] H. Vogt, J. Balej, J.E. Bennett, P. Wintzer, S.A. Sheikh, P. Gallone, Chlorine Oxides and Chlorine Oxygen Acids, Ullmann's Encycl. Ind. Chem., Wiley-VCH Verlag GmbH \& Co. KGaA, Weinheim, Germany, 2000, pp. 1-47.

[3] M. Grotheer, R. Alkire, R. Varjian, V. Srinivasan, J. Weidner, Industrial Electrolysis and Electrochemical Engineering, Electrochem. Soc. Interface 15 (2006) 52-54.

[4] S.S.L. Beraud, A. Gao, S. Davis, Sodium Chlorate - IHS Chemical Economics Handbook, (2015).

[5] M. Suhr, G. Klein, I. Kourti, M.R. Gonzalo, G.G. Santonja, S. Roudier, L.D. Sancho, Best Available Techniques (BAT) Reference Document for the Production of Pulp, Paper and Board, 2015.

[6] O. Carlsson, Förfaringssätt vid elektrolytisk framställning af alkaliklorater och perklorater, Patent No. SE11371, 1898

[7] H. Vogt, Electrosynthesis of Chlorate in the Nineteenth Century, J. Electrochem. Soc. 128 (1981) 29C.

[8] O. Carlson, Sätt att framställa klorater och perklorater, Patent No. SE19715, 1903

[9] J. Landin, Förfaringssätt vid framställning af klorater och perklorater, Patent No. SE8820, 1897.

[10] P. Imhoff, Manufacture of oxyhalogen salts, Patent No. US627063, 1899.

[11] H. Bischoff, F. Foerster, Beitrag zur Kenntnis der Elektrolyse von Chlorcalcium-lösungen, Berichte Der Bunsengesellschaft Für Phys. Chemie. 4 (1898) 464-470.

[12] E. Müller, Über ein elektrolytisches Verfahren zur Gewinnung der Chlor-, Brom- und Jodsauren Salze der Alkalien, Zeitschrift Für Elektrochemie 5 (1899) 469-473.

[13] European Chemicals Agency (ECHA), Background document for sodium dichromate, (2011)

[14] European Chemicals Agency, Recommendation of the European Chemicals Agency of 17 January 2013 for the Inclusion of substances in Annex XIV to REACH (List of Substances subject to Authorisation), 2013.

[15] European Chemicals Agency (ECHA), Authorization List (Annex XIV of REACH), 2015 (2015).

[16] Kemira Chemicals Oy, Analysis of Alteratives, Public Version - Sodium Dichromate, 2015.

[17] AkzoNobel Pulp and Performance Chemicals, Socio-Economic Analysis Public Version (Substance: sodium dichromate), 2015.

[18] Arkema France, Socio-Economic Analysis Public Version (Substance: sodium dichromate), 2015

[19] Kemira Chemical Oy, Socio-Economic Analysis Public Version (Substance: sodium dichromate), 2015

[20] S.A. Ercros, Socio-Economic Analyzis Public Version (Substance: sodium dichromate), 2015

[21] R.K.B. Karlsson, A. Cornell, Selectivity between Oxygen and Chlorine Evolution in the Chlor-Alkali and Chlorate Processes, Chem. Rev. 116 (2016) 2982-3028

[22] T.X. Wang, D.W. Margerum, Kinetics of Reversible Chlorine Hydrolysis: Temperature Dependence and General-Acid/Base-Assisted Mechanisms, Inorg. Chem. 33 (1994) 1050-1055.

[23] S. Sandin, R.K.B. Karlsson, A. Cornell, Catalyzed and Uncatalyzed Decomposition of Hypochlorite in Dilute Solutions, Ind. Eng. Chem. Res. 54 (2015) 3767-3774.

[24] B.V. Tilak, C.-P. Chen, Calculation of the current efficiency of the electrolytic sodium chlorate cells, J. Appl. Electrochem. 29 (1999) 1237-1240.

[25] R.E. Alford, Cyclochrome-The Recycle of Sodium Dichromate in Sodium Chlorate Manufacture, Mod. Chlor-Alkali Technol., Springer, Netherlands, Dordrecht, 1992, pp. 43-57.

[26] J. Wanngard, Impurity Effects in Chlorate Plants, Mod. Chlor-Alkali Technol. Springer, Netherlands, Dordrecht, 1992, pp. 295-306.

[27] A. Ahlberg Tidblad, G. Lindbergh, Surface analysis with ESCA and GD-OES of the film formed by cathodic reduction of chromate, Electrochim. Acta 36 (1991) 1605-1610.

[28] G. Lindbergh, D. Simonsson, Inhibition of cathode reactions in sodium hydroxide solution containing chromate, Electrochim. Acta 36 (1991) 19851994.

[29] A.A. Tidblad, J. Martensson, In situ ellipsometric characterization of films formed by cathodic reduction of chromate, Electrochim. Acta 42 (1997) 389398.

[30] I. Taniguchi, T. Sekine, Chemical reaction of chlorate formation, Denki Kagaku 43 (1975) 715-720.

[31] I. Taniguchi, S. Aoki, T. Sekine, Buffer action by dichromate addition on the chlorate cell process, Denki Kagaku 43 (1975) 532-534.

[32] I.M. Kolthoff, A.M.S.E. Din, Reduction of Hexavalent Chromium at the Rotated Platinum Electrode. Permeability of the Film Formed, J. Phys. Chem. 60 (1956) 1564-1568. 
[33] K. Hedenstedt, A.S.O. Gomes, M. Busch, E. Ahlberg, Study of Hypochlorite Reduction Related to the Sodium Chlorate Process, Electrocatalysis 7 (2016) 326-335.

[34] C. Wagner, The Cathodic Reduction of Anions and the Anodic Oxidation of Cations, J. Electrochem. Soc. 101 (1954) 181.

[35] B.V. Tilak, On the Mechanism of Sodium Chlorate Formation, J. Electrochem. Soc. 128 (1981) 1228.

[36] I. Taniguchi, T. Sekine, The influence of chromate addition on the cathodic reduction of hypochlorite ion, Denki Kagaku 43 (1975) 201-208.

[37] I. Taniguchi, T. Sekine, Cathodic reduction of chromate in alkaline solution, Denki Kagaku 43 (1975) 632-637.

[38] G. Lindbergh, D. Simonsson, The Effect of Chromate Addition on Cathodic Reduction of Hypochlorite in Hydroxide and Chlorate Solutions, J. Electrochem. Soc. 137 (1990) 3094.

[39] L. Hammar, G. Wranglén, Cathodic and anodic efficiency losses in chlorate electrolysis, Electrochim. Acta 9 (1964) 1-16.

[40] B.V. Tilak, Metal Anodes and Hydrogen Cathodes: Their Activity Towards $\mathrm{O}_{2}$ Evolution and $\mathrm{ClO}_{3}{ }^{-}$Reduction Reactions, J. Electrochem. Soc. 135 (1988) 1386.

[41] A. Cornell, D. Simonsson, Ruthenium Dioxide as Cathode Material for Hydrogen Evolution in Hydroxide and Chlorate Solutions, J. Electrochem. Soc. 140 (1993) 3123.

[42] J. Gustavsson, G. Li, C. Hummelgard, J. Backstrom, A. Cornell, On the suppression of cathodic hypochlorite reduction by electrolyte additions of molybdate and chromate ions, J. Electrochem. Sci. Eng. 2 (2012) 185-198.

[43] J. Wulff, A. Cornell, Cathodic current efficiency in the chlorate process, J. Appl. Electrochem. 37 (2007) 181-186.

[44] W.J. Clark, R.L. McCreery, Inhibition of Corrosion-Related Reduction Processes via Chromium Monolayer Formation, J. Electrochem. Soc. 149 (2002) B379.

[45] H.A. Duarte, K. Jha, J.W. Weidner, Electrochemical reduction of nitrates and nitrites in alkaline media in the presence of hexavalent chromium, J. Appl. Electrochem. 28 (1998) 811-817.

[46] M. Yoshida, K. Takanabe, K. Maeda, A. Ishikawa, J. Kubota, Y. Sakata, Y Ikezawa, K. Domen, Role and Function of Noble-Metal/Cr-Layer Core/Shell Structure Cocatalysts for Photocatalytic Overall Water Splitting Studied by Model Electrodes, J. Phys. Chem. C 113 (2009) 10151-10157.

[47] K. Maeda, K. Teramura, D. Lu, N. Saito, Y. Inoue, K. Domen, Noble-metal $/ \mathrm{Cr}_{2} \mathrm{O}_{3}$ core/shell nanoparticles as a cocatalyst for photocatalytic overall water splitting, Angew. Chemie Int. Ed. 45 (2006) 7806-7809.

[48] K. Maeda, K. Teramura, D. Lu, N. Saito, Y. Inoue, K. Domen, Roles of $\mathrm{Rh} / \mathrm{Cr}_{2} \mathrm{O}_{3}$ (Core/Shell) Nanoparticles Photodeposited on Visible-Light-Responsive ( $\mathrm{Ga}_{1}$ $\left.\mathrm{Zn}_{\mathrm{x}}\right)\left(\mathrm{N}_{1-\mathrm{x}} \mathrm{O}_{\mathrm{x}}\right)$ Solid Solutions in Photocatalytic Overall Water Splitting, J. Phys. Chem. C 111 (2007) 7554-7560.

[49] A. Cornell, G. Lindbergh, D. Simonsson, The effect of addition of chromate on the hydrogen evolution reaction and on iron oxidation in hydroxide and chlorate solutions, Electrochim. Acta 37 (1992) 1873-1881.

[50] G. Lindbergh, D. Simonsson, The effect of chromate addition on chlorate cathodes, Ext. Abstr. 172nd ECS Meet, Honolulu, Hawaii, 1987.

[51] R.M. Chapin, The Effect of Hydrogen-Ion Concentration on the Decomposition of Hypohalites, J. Am. Chem. Soc. 56 (1934) 2211-2215.

[52] L.C. Adam, I. Fabian, K. Suzuki, G. Gordon, Hypochlorous acid decomposition in the pH 5-8 region, Inorg. Chem. 31 (1992) 3534-3541.

[53] M.W. Lister, Decomposition of Sodium Hypochlorite: the Catalyzed Reaction, Can. J. Chem. 34 (1956) 479-488.

[54] J.W. Ball, D.K. Nordstrom, Critical Evaluation and Selection of Standard State Thermodynamic Properties for Chromium Metal and Its Aqueous Ions, Hydrolysis Species, Oxides, and Hydroxides, J. Chem. Eng. Data 43 (1998) 895-918.

[55] J.D. Ramsey, L. Xia, M.W. Kendig, R.L. McCreery, Raman spectroscopic analysis of the speciation of dilute chromate solutions, Corros. Sci. 43 (2001) $1557-$ 1572.

[56] F. Brito, J. Ascanio, S. Mateo, C. Hernández, L. Araujo, P. Gili, P. Martín-Zarza, S. Domínguez, A. Mederos, Equilibria of chromate(VI) species in acid medium and ab initio studies of these species, Polyhedron 16 (1997) 3835-3846.

[57] D.A. Palmer, D. Wesolowski, R.E. Mesmer, A potentiometric investigation of the hydrolysis of chromate (VI) ion in $\mathrm{NaCl}$ media to $175 \mathrm{C}$, J. Solution Chem. 16 (1987) 443-463.

[58] J.W. Ball, D.K. Nordstrom, Critical Evaluation and Selection of Standard State Thermodynamic Properties for Chromium Metal and Its Aqueous Ions, Hydrolysis Species, Oxides, and Hydroxides, J. Chem. Eng. Data 43 (1998) 895-918.

[59] J.D. Ramsey, L. Xia, M.W. Kendig, R.L. McCreery, Raman spectroscopic analysis of the speciation of dilute chromate solutions, Corros. Sci. 43 (2001) $1557-$ 1572.

[60] C.C. Hong, F. Lenzi, W.H. Rapson, The kinetics and mechanism of the chloridechlorate reaction, Can. J. Chem. Eng. 45 (1967) 349-355.

[61] G. Gordon, R.G. Kieffer, D.H. Rosenblatt, The Chemistry of Chlorine Dioxide, in: S.J. Lippard (Ed.), Prog. Inorg. Chem., Vol. 15, 1975, pp. 201-286.

[62] J.E. Colman, B.V. Tilak, Sodium Chlorate, in: J.J. McKetta, G.E. Weismante (Eds.), Encycl. Chem. Process. Des. Vol. 51 - Slurry Syst. Instrum. to SolidLiquid Sep., Marcel Dekker Inc., 1995, pp. 126-186.

[63] T.F. O'Brien, T.V. Bommaraju, F. Hine, Handbook of Chlor-Alkali Technology Volume II.: Brine Treatment and Cell Operation, Springer, US, Boston, MA, 2007.
[64] L. Nylén, A. Cornell, Effects of electrolyte parameters on the iron/steel cathode potential in the chlorate process, J. Appl. Electrochem. 39 (2009) 7181.

[65] M. Spasojević, N. Krstajić, M. Jakšić, Electrocatalytic optimization of faradaic yields in the chlorate cell process, Surf. Technol. 21 (1984) 19-26.

[66] M. Jaksic, A.R. Despic, B.Z. Nikolic, S.M. Maksic, Effect of Some Anions on the Chlorate Cell Process, Croat. Chem. Acta 44 (1972) 61-66.

[67] K. Viswanathan, B.V. Tilak, Chemical, Electrochemical, and Technological Aspects of Sodium Chlorate Manufacture, J. Electrochem. Soc. 131 (1984) 1551.

[68] J. Wanngård, The catalyzing effect of chromate in the chlorate formation reaction, Chem. Eng. Res. Des (2017) Accepted for publication.

[69] K.L. Hardee, L.K. Mitchell, The Influence of Electrolyte Parameters on the Percent Oxygen Evolved from a Chlorate Cell, J. Electrochem. Soc. 136 (1989) 3314.

[70] P. Byrne, E. Fontes, O. Parhammar, G. Lindbergh, A Simulation of the Tertiary Current Density Distribution from a Chlorate Cell: I. Mathematical Model, J. Electrochem. Soc. 148 (2001) D125.

[71] M.D. Spasojević, L.J. Ribić-Zelenović, P.M. Spasojević, B.Ž. Nikolić, Current efficiency in the chlorate cell process, J. Serbian Chem. Soc. 79 (2014) 677688.

[72] V.I. Eberil, N.S. Fedotova, E.A. Novikov, Polarization characteristics of metaloxide anodes based on ruthenium, iridium, and titanium oxides: a comparison with traditional DSA in the conditions Pertaining to sodium chlorate production, Russ. J. Electrochem. 33 (1997) 660-663.

[73] V.I. Eberil, N.S. Fedotova, E.A. Novikov, Polarization characteristics of DSA anodes in the conditions of obtaining sodium chlorate, Russ. J. Electrochem. 33 (1997) 563-569.

[74] L. Nyle'n, A. Cornell, Critical Anode Potential in the Chlorate Process, J. Electrochem. Soc. 153 (2006) D14.

[75] K.M. Macounová, N. Simic, E. Ahlberg, P. Krtil, Electrochemical WaterSplitting Based on Hypochlorite Oxidation, J. Am. Chem. Soc. 137 (2015) $7262-7265$.

[76] V.I. Ginzburg, L.G. Tetereva, Corrosion-electrochemical behavior of steel, titanium, and platinum cathodes in chloride-chlorate electrolytes, Russ. J. Electrochem. 8 (1972) 14-18.

[77] G. Ilevbare, G. Burstein, The inhibition of pitting corrosion of stainless steels by chromate and molybdate ions, Corros. Sci. 45 (2003) 1545-1569.

[78] M.W. Kendig, R.G. Buchheit, Corrosion Inhibition of Aluminum and Aluminum Alloys by Soluble Chromates, Chromate Coatings, and Chromate-Free Coatings, Corrosion 59 (2003) 379-400.

[79] G. Lu, E.T. Ada, G. Zangari, Investigations of the effect of chromate conversion coatings on the corrosion resistance of Ni-based alloys, Electrochim. Acta 49 (2004) 1461-1473.

[80] K. Hedenstedt, Electrochemical Investigations of Water and Hypochlorite Reduction on $\alpha$-and y-FeOOH - Licentiate thesis, University of Gothenburg, 2015.

[81] T.F. O'Brien, T.V. Bommaraju, F. Hine, Handbook of Chlor-Alkali Technology Volume I.: Fundamentals, Springer, US, Boston MA, 2005.

[82] A.T. Kuhn, H. Hamzah, G.C.S. Collins, The inhibition of the cathodic reduction of hypochlorite by films deposited at the cathode surface, J. Chem. Technol. Biotechnol. 30 (1980) 423-428.

[83] J. Gustavsson, L. Nylén, A. Cornell, Rare earth metal salts as potential alternatives to $\mathrm{Cr}(\mathrm{VI})$ in the chlorate process, J. Appl. Electrochem. 40 (2010) $1529-1536$

[84] K. Hedenstedt, R.E. Albers, Electrolytic process, Patent No. US 2013/0292261 A1, 2013.

[85] M. Li, Z. Twardowski, F. Mok, N. Tam, Sodium molybdate-a possible alternate additive for sodium dichromate in the electrolytic production of sodium chlorate, J. Appl. Electrochem. 37 (2007) 499-504.

[86] J. Gustavsson, C. Hummelgard, J. Backstrom, I.O. Wallinder, S.M. Rahman, G. Lindbergh, S. Eriksson, A. Cornell, In-situ activated hydrogen evolution by molybdate addition to neutral and alkaline electrolytes, J. Electrochem. Sci. Eng. 2 (2012) 105-120.

[87] T. Nagai, T. Takei, Reduction at cathode and its prevention by chromium plated cathode in chlorate production, J. Electrochem. Soc. Japan 25 (1957) 373-377.

[88] S. Jin, A. Van Neste, E. Ghali, S. Boily, R. Schulz, New Cathode Materials for Chlorate Electrolysis, J. Electrochem. Soc. 144 (1997) 4272.

[89] P. Kohl, K. Lohrberg, Material problems in the three versions of chloralkali electrolysis, J. Appl. Electrochem. 19 (1989) 589-595.

[90] A. Gebert, M. Lacroix, O. Savadogo, R. Schulz, Cathodes for chlorate electrolysis with nanocrystalline Ti-Ru-Fe-O catalyst, J. Appl. Electrochem. 30 (2000) 1061-1067.

[91] M.-L. Tremblay, C. Chabanier, D. Guay, Effect of Chromium Additives to Nanocrystalline Ti:Ru:Fe:O on the Reduction of Hypochlorite, J. Electrochem. Soc. 152 (2005) E265.

[92] F. Herlitz, Inhibiting effect of oxidized zirconium on parasitic cathodic reactions in the sodium chlorate process. Part I: Hypochlorite reduction, J. Appl. Electrochem. 31 (2001) 307-312.

[93] U.Č. Lačnjevac, B.M. Jović, L.M. Gajić-Krstajić, J. Kovač, V.D. Jović, N.V. Krstajić, Ti substrate coated with composite $\mathrm{Cr}-\mathrm{MoO}_{2}$ coatings as highly selective cathode materials in hypochlorite production, Electrochim. Acta 96 (2013) $34-42$. 
[94] L. Gajic-Krstajic, N. Elezovic, B. Jovic, G. Martelli, V. Jovic, N. Krstajic, Fe-Mo alloy coatings as cathodes in chlorate production process, Hem. Ind. 70 (2016) 81-89.

[95] T.V. Bommaraju, T.H. Dexter, C.G. Rader, Film-coated cathodes for halate cell US 4295951 A (1981).

[96] D.W. Wakerley, E. Reisner, Oxygen-tolerant proton reduction catalysis: much $\mathrm{O}_{2}$ about nothing? Energy Environ. Sci. 8 (2015) 2283-2295.

[97] Y. Matsumoto, U. Unal, N. Tanaka, A. Kudo, H. Kato, Electrochemical approach to evaluate the mechanism of photocatalytic water splitting on oxide photocatalysts, J. Solid State Chem. 177 (2004) 4205-4212.

[98] D. Eisenberg, H.S. Ahn, A.J. Bard, Enhanced Photoelectrochemical Water Oxidation on Bismuth Vanadate by Electrodeposition of Amorphous Titanium Dioxide, J. Am. Chem. Soc. 136 (2014) 14011-14014.

[99] M. Yoshida, K. Maeda, D. Lu, J. Kubota, K. Domen, Lanthanoid Oxide Layers on Rhodium-Loaded $\left(\mathrm{Ga}_{1-\mathrm{x}} \mathrm{Zn}_{\mathrm{x}}\right)\left(\mathrm{N}_{1-\mathrm{x}} \mathrm{O}_{\mathrm{x}}\right)$ Photocatalyst as a Modifier for Overall Water Splitting under Visible-Light Irradiation, J. Phys. Chem. C 117 (2013) 14000-14006.

[100] C. Pan, T. Takata, M. Nakabayashi, T. Matsumoto, N. Shibata, Y. Ikuhara, K. Domen, A Complex Perovskite-Type Oxynitride: The First Photocatalyst for Water Splitting Operable at up to 600 nm, Angew. Chemie Int. Ed. 54 (2015) 2955-2959.

[101] G. Yuan, A. Agiral, N. Pellet, W. Kim, H. Frei, Inorganic core-shell assemblies for closing the artificial photosynthetic cycle, Faraday Discuss. 176 (2014) 233-249.

[102] S. Chatterjee, K. Sengupta, S. Dey, A. Dey, Ammonium Tetrathiomolybdate: A Versatile Catalyst for Hydrogen Evolution Reaction from Water under Ambient and Hostile Conditions, Inorg. Chem. 52 (2013) 14168-14177.

[103] P.A. Sørensen, S. Kiil, K. Dam-Johansen, C.E. Weinell, Anticorrosive coatings: a review, J. Coatings Technol. Res. 6 (2009) 135-176.

[104] J.E. Gray, B. Luan, Protective coatings on magnesium and its alloys-a critical review, J. Alloys Compd. 336 (2002) 88-113.

[105] B.R.W. Hinton, Corrosion inhibition with rare earth metal salts, J. Alloys Compd. 180 (1992) 15-25.

[106] D. Wang, G.P. Bierwagen, Sol-gel coatings on metals for corrosion protection, Prog. Org. Coatings 64 (2009) 327-338.

[107] M. Schem, T. Schmidt, J. Gerwann, M. Wittmar, M. Veith, G.E. Thompson, I.S. Molchan, T. Hashimoto, P. Skeldon, A.R. Phani, S. Santucci, M.L. Zheludkevich, $\mathrm{CeO}_{2}$-filled sol-gel coatings for corrosion protection of AA2024-T3 aluminium alloy, Corros. Sci. 51 (2009) 2304-2315.

[108] F. Zhang, M. Sun, S. Xu, L. Zhao, B. Zhang, Fabrication of oriented layered double hydroxide films by spin coating and their use in corrosion protection, Chem. Eng. J. 141 (2008) 362-367.

[109] W. Funke, Organic Coatings in Corrosion Protection, Surf. Coatings-2, Springer, Netherlands, Dordrecht, 1988, pp. 107-135.

[110] M. Paidar, V. Fateev, K. Bouzek, Membrane electrolysis-History, current status and perspective, Electrochim. Acta 209 (2016) 737-756.

[111] T. Xu, Ion exchange membranes: State of their development and perspective, J. Memb. Sci. 263 (2005) 1-29.

[112] N. Krstajić, V. Nakić, M. Spasojević, Hypochlorite production II. Direct electrolysis in a cell divided by an anionic membrane, J. Appl. Electrochem. 21 (1991) 637-641.

[113] I. Moussallem, J. Jörissen, U. Kunz, S. Pinnow, T. Turek, Chlor-alkali electrolysis with oxygen depolarized cathodes: history, present status and future prospects, J. Appl. Electrochem. 38 (2008) 1177-1194.

[114] A. Tenney, T. Pavone, Bayer-ThyssenKrupp ODC (Oxygen Depolarized Cathode) Chlor-Alkali Technology, Process Econ. Progr. Rev. (2015) 1-120.

[115] B. Hakansson, E. Fontes, F. Herlity, V. Lindstrand, Process for producing alkali metal chlorate, US 2004/0124094 A1 (2004).

[116] E.E. Kalu, C. Oloman, Simultaneous electrosynthesis of alkaline hydrogen peroxide and sodium chlorate, J. Appl. Electrochem. 20 (1990) 932-940.

[117] L. Lipp, S. Gottesfeld, J. Chlistunoff, Peroxide Formation in a Zero-Gap ChlorAlkali Cell with an Oxygen-Depolarized Cathode, J. Appl. Electrochem. 35 (2005) 1015-1024.
[118] T.E. Lister, E.J. Dufek, Chlor-syngas: Coupling of Electrochemical Technologies for Production of Commodity Chemicals, Energy \& Fuels 27 (2013) 42444249.

[119] S. Lakshmanan, T. Murugesan, The chlor-alkali process: Work in Progress, Clean Technol. Environ. Policy 16 (2014) 225-234.

[120] P. Schmittinger, T. Florkiewicz, L.C. Curlin, B. Lüke, R. Scannell, T. Navin, E. Zelfel, R. Bartsch, Chlorine, Ullmann's Encycl. Ind. Chem, Wiley-VCH Verlag GmbH \& Co. KGaA, Weinheim, Germany, 2011.

[121] L.C. Adam, G. Gordon, Hypochlorite Ion Decomposition: Effects of Temperature, Ionic Strength, and Chloride Ion, Inorg. Chem. 38 (1999) 1299-1304.

[122] M.W. Lister, The decomposition of hypochlorous acid, Can. J. Chem. 30 (1952) 879-889.

[123] M.W. Lister, Decomposition of sodium hypochlorite: The uncatalyzed reaction, Can. J. Chem. 34 (1956) 465-478.

[124] G.H. Ayres, M.H. Booth, Catalytic Decomposition of Hypochlorite Solution by Iridium Compounds. I. The pH-Time Relationship, J. Am. Chem. Soc. 77 (1955) $825-827$.

[125] G.H. Ayres, M.H. Booth, Catalytic Decomposition of Hypochlorite Solution by Iridium Compounds. II. Kinetic Studies, J. Am. Chem. Soc. 77 (1955) 828-833.

[126] E. Chirnoaga, CCXXII.-The catalytic decomposition of solutions of sodium hypochlorite by finely divided metallic oxides, J. Chem. Soc. 129 (1926) $1693-$ 1703.

[127] O.R. Howell, The Catalytic Decomposition of Sodium Hypochlorite by Cobalt Peroxide, Proc. R. Soc. London Ser. A Contain. Pap. A Math. Phys. Character 104 (1923) 134-152.

[128] J.A. Church, Kinetics of the Uncatalyzed and $\mathrm{Cu}(\mathrm{II})$-Catalyzed Decomposition of Sodium Hypochlorite, Ind. Eng. Chem. Res. 33 (1994) 239-245.

[129] J.R. Lewis, The Catalytic Decomposition of Sodium Hypochlorite Solutions. I. Mechanism of the Reaction, J. Phys. Chem. 32 (1928) 243-254.

[130] J.R. Lewis, The Catalytic Decomposition of Sodium Hypochlorite Solutions. II. Iron Oxide as Promoter in the Copper Oxide Catalysis of Sodium Hypochlorite, J. Phys. Chem. 32 (1928) 1808-1819.

[131] J.R. Lewis, The Catalytic Decomposition of Sodium Hypochlorite Solutions. III Promoter Action of Hydrated Magnesium Oxide in the Hydrated Copper Oxide Catalysis of Sodium Hypochlorite, J. Phys. Chem. 35 (1931) 915-919.

[132] A. Hamano, K. Takakura, I. Nakamori, The effect of $\mathrm{pH}$ on the catalytic decomposition of aqueous sodium hypochlorite by cobalt oxide, Kayak. Gakkaishi. 59 (1998) 174-180.

[133] K.W. Kim, E.H. Lee, D.Y. Chung, J.K. Moon, H.S. Shin, J.S. Kim, D.W. Shin, Manufacture characteristics of metal oxide-hydroxides for the catalytic decomposition of a sodium hypochlorite solution, Chem. Eng. J. 200-202 (2012) 52-58.

[134] E.T. Gray, R.W. Taylor, D.W. Margerum, Kinetics and mechanisms of the copper-catalyzed decomposition of hypochlorite and hypobromite. Properties of a dimeric copper(III) hydroxide intermediate, Inorg. Chem. 16 (1977) 3047-3055.

[135] T.J. Mason, A. Newman, J.P. Lorimer, J. Lindley, K. Hutt, Ultrasonically assisted catalytic decomposition of aqueous sodium hypochlorite, Ultrason. Sonochem. 3 (1996) 53-55.

[136] K.A. Hofmann, K. Ritter, Beständigkeit und Oxydationspotential der Hypochlorite, Beiträge zur Katalyse und über ein Hypochlorit-KohleElement, Berichte Der Dtsch. Chem. Gesellschaft. 47 (1914) 2233-2244.

[137] R.A. Kus, Effects of Electrolyte Impurities in Chlorate Cells, 16th Annu. Chlorine/Chlorate Semin., Cleveland, Ohio, 2000, pp. 1-22.

[138] P. Wilfert, P.S. Kumar, L. Korving, G.-J. Witkamp, M.C.M. van Loosdrecht, The Relevance of Phosphorus and Iron Chemistry to the Recovery of Phosphorus from Wastewater: A Review, Environ. Sci. Technol. 49 (2015) 9400-9414.

[139] M. Spasojevic, N. Krstajic, M. Jaksic, A Selective Catalyst for Titanium Anodes: Development and Optimization. II. Selectivity Features, J. Res. Inst. Catal. Hokkaido Univ. 32 (1984) 29-36. 